\title{
Adsorption Energy Engineering of Nickel Oxide Hybrid Nanosheets for High Areal Capacity Flexible Lithium-Ion Batteries
}

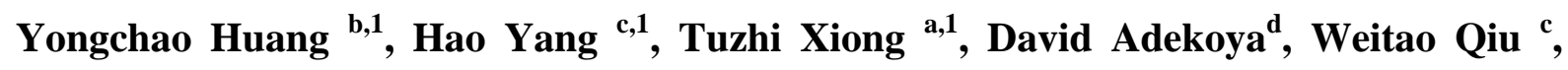
Zhongmin Wang $^{\mathrm{e}, *}$, Shanqing Zhang ${ }^{\mathrm{d}, *}$, M.-Sadeeq Balogun (Jie Tang) ${ }^{\mathrm{a}, *}$

${ }^{a}$ College of Materials Science and Engineering, Hunan University, Changsha 410082, China.

${ }^{\mathrm{b}}$ Institute of Environmental Research at Greater Bay, Key Laboratory for Water Quality and Conservation of the Pearl River Delta, Ministry of Education, Guangzhou University, Guangzhou 510006, People's Republic of China

${ }^{c}$ MOE of the Key Laboratory of Bioinorganic and Synthetic Chemistry, The Key Lab of Low-carbon Chemistry \& Energy Conservation of Guangdong Province, KLGHEI of Environment and Energy Chemistry, School of Materials Science and Engineering, School of Chemistry, Sun Yat-sen University, Guangzhou 510275, China.

${ }^{\mathrm{d} C e n t r e}$ for Clean Environment and Energy, Griffith School of Environment, Gold Coast Campus, Griffith University, QLD 4222, Australia.

${ }^{\mathrm{e}}$ School of Materials Science and Engineering, Guilin University of Electronic Technology, Guilin, 541004, P.R. China.

Corresponding Authors E-mail: zmwang@ guet.edu.cn; s.zhang@ griffith.edu.au; balogun@hnu.edu.cn 


\begin{abstract}
Enriching electrode materials with definite functions is of great influence but highly challenging towards achieving high areal capacity lithium ion batteries (LIBs). Taking transition metal oxides (TMOs) as a case study, several attempts have been employed to demonstrate the large variations in lithium storage performance of TMOs, but explanation of the adsorption capability is rarely reported. Herein, the Li-ion storage chemistry of $\mathrm{NiO}$ nanosheets is successfully enhanced by modulating the position of the p-orbital energy level via engineering with porous $\mathrm{N}$-doped carbon fiber and carbon quantum dots (CDs). The asprepared monolithic $\mathrm{NiO}$ hybrid nanosheets (denoted $\mathrm{CF} / \mathrm{ECF} / \mathrm{NiO} / \mathrm{CD}$ ) exhibit high reversible areal capacity of $3.97 \mathrm{mAh} \mathrm{cm}^{-2}$ at $0.25 \mathrm{~mA} \mathrm{~cm}$, excellent cyclic stability with capacity of $2.91 \mathrm{mAh} \mathrm{cm}^{-2}$ at $3.0 \mathrm{~mA} \mathrm{~cm}$, as well as attractive rate capacity of $2.61 \mathrm{mAh}$ $\mathrm{cm}^{-2}$ at $6.0 \mathrm{~mA} \mathrm{~cm} \mathrm{~cm}^{-2}$. In situ Raman analyses, XPS, and DFT calculations reveal that performance enhancement is related to the electronic modulations between $\mathrm{NiO}$, porous carbon fiber and CDs that triggers the shift of the p-band towards accommodating interfacial electron transfer that helps in promoting the Li storage activity. In addition, an all-flexible lithium ion battery based on $\mathrm{CF} / \mathrm{ECF} / \mathrm{NiO} / \mathrm{CD}$ anode is assembled and a volumetric energy density of $619.9 \mathrm{Wh} \mathrm{L}^{-1}$ is achieved (equivalent to an energy density of $201.7 \mathrm{Wh} \mathrm{kg}^{-1}$ ). This work opens an achievable approach for high-areal-capacity LIBs and provides relevant understanding into designing other LIB electrodes and beyond.
\end{abstract}

\title{
Keywords
}

monolithic electrode, high areal capacity, electronic interaction, adsorption energy, density functional theory 



\section{Introduction}

Considering the future application of lithium ion batteries (LIBs) in the area of consumer electronics, aerospace, vehicle electrification, LIBs with high areal capacities require serious alleviation, but the main challenge is the electrode materials [1-4]. Due to the high theoretical capacities of transition metal oxides (TMOs) as anode materials for LIBs [5-7], extensive recognition has been given to them but their dependability towards practical application relics a critical challenge [8-10]. Especially in most cases that these TMO electrodes are usually prepared in their powdery forms and their Li storage performance is evaluated based on the active materials $[11,12]$, this could create undesirable inactive volume and uneven electrochemical environment for $\mathrm{Li}$ storage reactions. Additionally, it usually leads to the use of low mass loading of the active materials, tediousness in battery electrode fabrication and as a result, more-time consumption for electrode preparation and low areal capacity will be achieved [11, 13]. In such condition, it remains a crucial challenge to essentially design TMO electrode with distinct features that could display high areal capacity coupled with stable cycle life $[14,15]$.

To embrace this challenge, most reports adopted the design of TMOs nanostructures on three dimensional (3D) current collectors such as transition metal foams, conductive carbon based substrates $[11,12,16-20]$ etc. The major contest is the issue of poor adhesion of active materials on these $3 \mathrm{D}$ substrates due to weak interaction leading to peeling-off of active material from the substrates after continuous lithiation processes $[21,22]$. Taking $\mathrm{NiO}$ as a case study, Li et al. recently constructed 3D layer-by-layer NiO-based freestanding 
structures obtained from partial oxidation of NF, which could reinforces adhesion with active layer, contributes to the capacity of the whole electrode and delivers an areal capacity of $1.98 \mathrm{mAh} \mathrm{cm}^{-2}$ at $1.20 \mathrm{~mA} \mathrm{~cm}^{-2}$ [11]. With the impressive advancement accomplished with 3D $\mathrm{NiO}$, their overall $\mathrm{Li}$ storage performance still requires further improvement $[11,12,15,17]$. In addition, a large variation in performance of TMOs has been reported, but the underlying mechanism towards understanding these variations, especially in terms of the fundamental modulation and adsorption ability of the TMOs metal centers for Li storage attracts less understanding.

Herein, we favourably modulate $\mathrm{NiO}$ nanosheets as flexible anode for high areal capacity LIB by engineering the p-orbital through the design of monolithic or all-in-one multishell architecture. The all-in-one architecture consists of flexible carbon fiber coated with exfoliated porous $\mathrm{N}$-doped carbon fiber (denoted $\mathrm{CF} / \mathrm{ECF}$ ) current collector (as capacity contributor), $\mathrm{NiO}$ nanosheets (as active layer) and carbon quantum dots (CDs) (as stabilizer) (denoted $\mathrm{CF} / \mathrm{ECF} / \mathrm{NiO} / \mathrm{CD})$. The multishell $\mathrm{CF} / \mathrm{ECF} / \mathrm{NiO} / \mathrm{CD}$ shows excellent $\mathrm{Li}$ storage performance as anode material for LIB half-cell delivering an initial and reversible areal capacity up to 4.33 and $3.97 \mathrm{mAh} \mathrm{cm}^{-2}$ at $0.25 \mathrm{~mA} \mathrm{~cm}$, respectively, areal capacity of $2.91 \mathrm{mAh} \mathrm{cm}^{-2}$ at $3.0 \mathrm{~mA} \mathrm{~cm}{ }^{-2}$ as well as attractive rate capability capacity of $2.61 \mathrm{mAh} \mathrm{cm}^{-2}$ at $6.0 \mathrm{~mA} \mathrm{~cm}{ }^{-2}$. In-situ Raman spectra, XPS analyses and density functional theory (DFT) calculations persistently show that the enhanced capacity, excellent conductivity and outstanding stability of $\mathrm{CF} / \mathrm{ECF} / \mathrm{NiO} / \mathrm{CD}$ electrode cannot be attributed only to the synergistic effect, monolithic nature and capacity contribution from the $\mathrm{CF} / \mathrm{ECF}$ current collector, but also the shift of p-orbital center, which enables 
the modulation of Li-ion diffusion pathway and interfacial electron transfer. This work provides helpful insights for enhancing the areal capacity of LIB and interpreting the large variation in the performance of TMOs via orbital engineering.

\section{Experimental}

\subsection{Materials}

Carbon textile was purchased from Fuel Cell Earth LLC, United States. $\mathrm{Ni}\left(\mathrm{NO}_{3}\right)_{2} \cdot 6 \mathrm{H}_{2} \mathrm{O}$, Hexamethylene, concentrated $\mathrm{HNO}_{3}, \mathrm{NH}_{4} \mathrm{VO}_{3}$, sucrose and ethanol (99.7\%) were all purchased from Guangzhou Chemical Reagent Factory and used as received without further purification.

\subsection{Synthesis of the CF/ECF}

$\mathrm{CF} / \mathrm{ECF}$ was prepared according to our previous report. [22] In a typical synthesis, after the cleaning of commercial carbon fiber (CF) in concentrated $\mathrm{HNO}_{3}$, distilled water and ethanol for several times, the clean CF was immersed in a $30 \mathrm{~min}$ well-stirred solution of $10 \mathrm{mmol} \mathrm{Ni}\left(\mathrm{NO}_{3}\right)_{2} \cdot 6 \mathrm{H}_{2} \mathrm{O}$ and $20 \mathrm{mmol}$ Hexamethylene (HMT) dissolved in $40 \mathrm{~mL}$ of deionized water and vigorously stirred for another $10 \mathrm{~min}$. The solution and CF were transferred to a $50 \mathrm{~mL}$ Teflon-lined stainless-steel autoclave and heated in an electric oven with a heating speed of $10{ }^{\circ} \mathrm{C} \mathrm{min}{ }^{-1}$ to $120{ }^{\circ} \mathrm{C}$ and maintained in an oven for $10 \mathrm{~h}$ and then allow naturally to cool to room temperature. After cooling down to room temperature, the Ni precursor/CF was washed with water, ethanol for several times and dried in $60{ }^{\circ} \mathrm{C}$ oven overnight and annealed in $\mathrm{N}_{2}$ atmosphere at 900 ${ }^{\circ} \mathrm{C}$ for 90 min with heating speed of $10{ }^{\circ} \mathrm{C} \min ^{-1}$ to $900{ }^{\circ} \mathrm{C}(1 \mathrm{bar}, 200 \mathrm{sccm})$. The product obtained after annealing was then immersed in conc. $\mathrm{HCl}$ for 12 
hours to remove the Ni NPs and obtain porous exfoliated N-doped carbon cloth (denoted as $\mathrm{CF} / \mathrm{ECF}$ ).

\subsection{Synthesis of $\mathrm{CF} / \mathrm{ECF} / \mathrm{NiO}$}

$\mathrm{CF} / \mathrm{ECF} / \mathrm{NiO}$ was formed by using as-prepared $\mathrm{CF} / \mathrm{ECF}$ as a starting substrate and the hydrothermal growth for the Ni precursor was repeated. The product derived was then annealed in air at $500{ }^{\circ} \mathrm{C}$ for $3 \mathrm{~h}$ with heating rate of $10{ }^{\circ} \mathrm{C}$ $\min ^{-1}$ to obtain the final product $\mathrm{CF} / \mathrm{ECF} / \mathrm{NiO}$.

\subsection{Synthesis of $\mathrm{CF} / \mathrm{ECF} / \mathrm{NiO} / \mathrm{CD}$}

First carbon dots (CD) solution was prepared according to a previous work. [23] In a typical synthesis, $3.42 \mathrm{~g}$ sucrose was dissolved in $100 \mathrm{~mL}$ of distilled water and the solution was transferred to a $100 \mathrm{~mL}$ Teflon-lined autoclave. The autoclave was heated in an electric oven at $160{ }^{\circ} \mathrm{C}$ for $3 \mathrm{~h}$, and then allowed the electric oven to cool to room temperature. Upon cooling, the solution undergoes centrifugation and dried at $80{ }^{\circ} \mathrm{C}$ for 24 hours to obtain the $\mathrm{CD}$ powder. The $\mathrm{CD}$ powder obtained was dispersed in ethanol (99.99\%) through ultra-sonication, and then centrifuged to collect the residue and precipitate solution. $\mathrm{CF} / \mathrm{ECF} / \mathrm{NiO}$ was immersed in the precipitated solution obtained for $6 \mathrm{~h}$. After $6 \mathrm{~h}$, the sample was removed from the precipitated solution and directly dried in the electric oven at $60{ }^{\circ} \mathrm{C}$ overnight to obtain $\mathrm{CF} / \mathrm{ECF} / \mathrm{NiO} / \mathrm{CD}$.

\subsection{Synthesis of $\mathrm{CF} / \mathrm{NiO}$}

$\mathrm{CF} @ \mathrm{NiO}$ was prepared exactly the same way as the $\mathrm{CF} / \mathrm{ECF} / \mathrm{NiO}$ but $\mathrm{CF}$ was used as the substrate instead of the CF/ECF.

\subsection{Characterization}

Field emission SEM (JSM-6330F) and transmission electron microscope (TEM) (JEM2010-HR, $200 \mathrm{KV}$ ) were used to characterize the morphology, structure, 
and composition of the samples. X-ray Photoelectron spectroscopy (XPS, ESCALab250) was used for element identification and heteroatom functional group distribution. X-ray diffraction Spectrometry (XRD; Shimadzu X-ray diffractometer 6000, Cu Karadiation, Shimadzu, Tokyo, Japan) and Raman Spectroscopy (Renishaw inVia) were used to characterize the crystallographic information and phase purity of the samples.

\subsection{Electrochemical Measurement}

The lithium storage performance tests were carried out via CR2032 coin type cells. The electrodes were first cut into many smaller square pieces with the diameter of area of $1.0 \mathrm{~cm}^{2}$. The working electrodes, $\mathrm{CF} / \mathrm{NiO}, \mathrm{CF} / \mathrm{ECF} / \mathrm{NiO}$ and $\mathrm{CF} / \mathrm{ECF} / \mathrm{NiO} / \mathrm{CD}$, lithium foil (serving as the counter and reference electrode) and Celgard 2400 separator to separate the electrodes. The mass loading of the $\mathrm{CF} / \mathrm{NiO}, \mathrm{CF} / \mathrm{ECF} / \mathrm{NiO}$ and $\mathrm{CF} / \mathrm{ECF} / \mathrm{NiO} / \mathrm{CD}$ electrodes based on the entire area of $1.0 \mathrm{~cm}^{2}$ are $12.20,10.54$ and $10.58 \mathrm{mg} \mathrm{cm}^{-2}$, respectively. The batteries were assembled in an argon-filled glove box [Mikrouna (China) Co., Ltd.] with an organic liquid electrolyte that consists of $1 \mathrm{M} \mathrm{LiPF}_{6}$ in $1: 1$ by volume of ethylene carbonate (EC)/dimethyl carbonate (DMC) was used. The cells were aged for 8-10 $\mathrm{h}$ before electrochemical test. The discharge and charge measurements were carried out on a Neware battery tester (CT-3008-164, Shenzhen, China). The voltage range for the battery testing are 0.01-3.0 V (vs. $\mathrm{Li} / \mathrm{Li}^{+}$) for the anode and 2.0-4.0 V (vs. $\mathrm{Li} / \mathrm{Li}^{+}$) for the cathode. The storage capacities were calculated based on current*hour per unit area i.e. $\mathrm{mAh} \mathrm{cm}^{-2}$. Cyclic voltammetry (CV) were conducted on electrochemical working station (CHI 1040c, Chenhua, Shanghai) at a scan rate of $0.1 \mathrm{mV} \mathrm{s}^{-1}$. Electrochemical impedance spectroscopy (EIS) was measured on an AC voltage of $5 \mathrm{mV}$ 
amplitude in the frequency range from $100 \mathrm{kHz}$ to $0.1 \mathrm{~Hz}$ using an electrochemical workstation (CHI660D, Chenhua, Shanghai). The tests were carried out after the cells were assembled before and after cycling.

2.8. Assembling of the flexible lithium ion battery (FLIB) and storage measurement.

Commercial $\mathrm{LiNiCoMnO}_{2}$ (LNCMO) purchased from Shenzhen Kejing Star Technology Co., LTD, was employed as the cathode. $4 \mathrm{~cm} \times 6 \mathrm{~cm}$ Anodes $(\mathrm{CF} / \mathrm{NiO}$ and $\mathrm{CF} / \mathrm{ECF} / \mathrm{NiO} / \mathrm{CD})$ and $\mathrm{CF} / \mathrm{ECF} / \mathrm{LNCMO}$ cathode with mass loading of 81 and $222 \mathrm{mg}$ was synthesised, respectively. Based on our previous work, CF/ECF/LNCMO could deliver a capacity of $265 \mathrm{mAh} \mathrm{g}^{-1}$ [22]. The theoretical capacity of $\mathrm{NiO}$ is $720 \mathrm{mAh} \mathrm{g}^{-1}$. The criterion for the mass ratio between is that we utilized about 3 folds of the LNCMO cathode material to match the capacity of the anode. Nickel strip was attached to both electrodes as current collectors. The electrolyte used is $1 \mathrm{M} \mathrm{LiPF}_{6}$ in $1: 1$ by volume of ethylene carbonate (EC)/dimethyl carbonate (DMC), while the separator used to separate anode from cathode is also Celgard 2400 separator. All the battery components assembled into aluminium bag and sealed in the argon-filled glove box. The total weight of the FLIB device is $308 \mathrm{mg}$ and the thickness is $0.1 \mathrm{~cm}$. The potential range for testing the FLIB is $2.0-4.0 \mathrm{~V}$. Cyclic voltammetry (CV) were conducted on electrochemical working station (CHI 1040c, Chenhua, Shanghai) at a scan rate of $0.1 \mathrm{mV} \mathrm{s}^{-1}$. The storage capacities were calculated based on current*hour per unit area i.e. $\mathrm{mAh} \mathrm{g}^{-1}, \mathrm{mAh} \mathrm{cm}^{-2}$ and $\mathrm{mAh} \mathrm{cm}^{-3}$. The lithium storage measurement of the battery was tested by applying direct current values of 5.0, 10.0 and $15.0 \mathrm{~mA}$ also using Neware battery tester (CT3008-164, Shenzhen, China). The batteries were first cycled for 10 cycles to 
maintain its stability and avoid other side reactions. The electrochemical data reported for the FLIB are data recorded after initial 10 electrochemical cycles. The volumetric and mass energy densities were also calculated.

\subsection{Computational Methodology}

The entire calculations have been performed with the Vienna ab initio Simulation Package (VASP) [24]. 3D periodic boundary conditions were used to simulate the infinitely large systems. The vacuum space between sheets was adjusted to $20 \AA$ to prevent the two membrane layers interaction. The fibre Brillouin zone was sampled by $1 \times 3 \times 1$ k-points. The system electronic structure was manipulated using the generalized gradient approximation with the PBE functional [25]. The van der Waals interactions were added to the standard DFT description by Grimme's D2 scheme [26]. All calculations include spin polarization. During the entire calculations, the convergence parameters were $10^{-6} \mathrm{eV}$ for the energy, $0.01 \mathrm{eV}^{-1}$ for the forces and an energy cut-off of $500 \mathrm{eV}$. A Gaussian smearing of $0.05 \mathrm{eV}$ was also applied. Charge analysis was performed via Bader analysis [27], which included the core charges and charge density difference analysis within VASP.

\section{Results}

\subsection{Morphological and Composition Characterization}

$\mathrm{CF} / \mathrm{ECF} / \mathrm{NiO} / \mathrm{CD}$ monolithic flexible anode was designed via hydrothermal, annealing and chemical bath reactions so as to address the issue of developing high areal capacity LIBs as shown in Figure 1a-i-ii. To achieve this, $\mathrm{CF} / \mathrm{ECF} / \mathrm{NiO} / \mathrm{CD}$ was designed using porous and $\mathrm{N}$-doped exfoliated flexible carbon fiber $(\mathrm{CF} / \mathrm{ECF})$ as substrate. 
$\mathbf{a}$

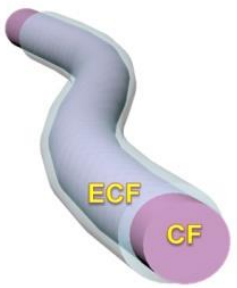

CF/ECF

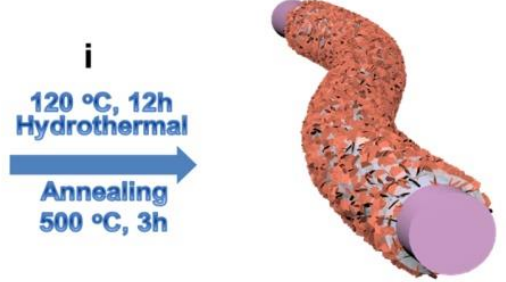

CF/ECF/NIO

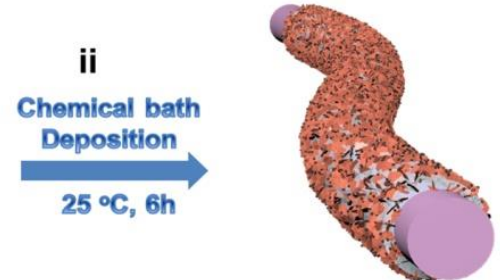

CF/ECF/NIO/CD
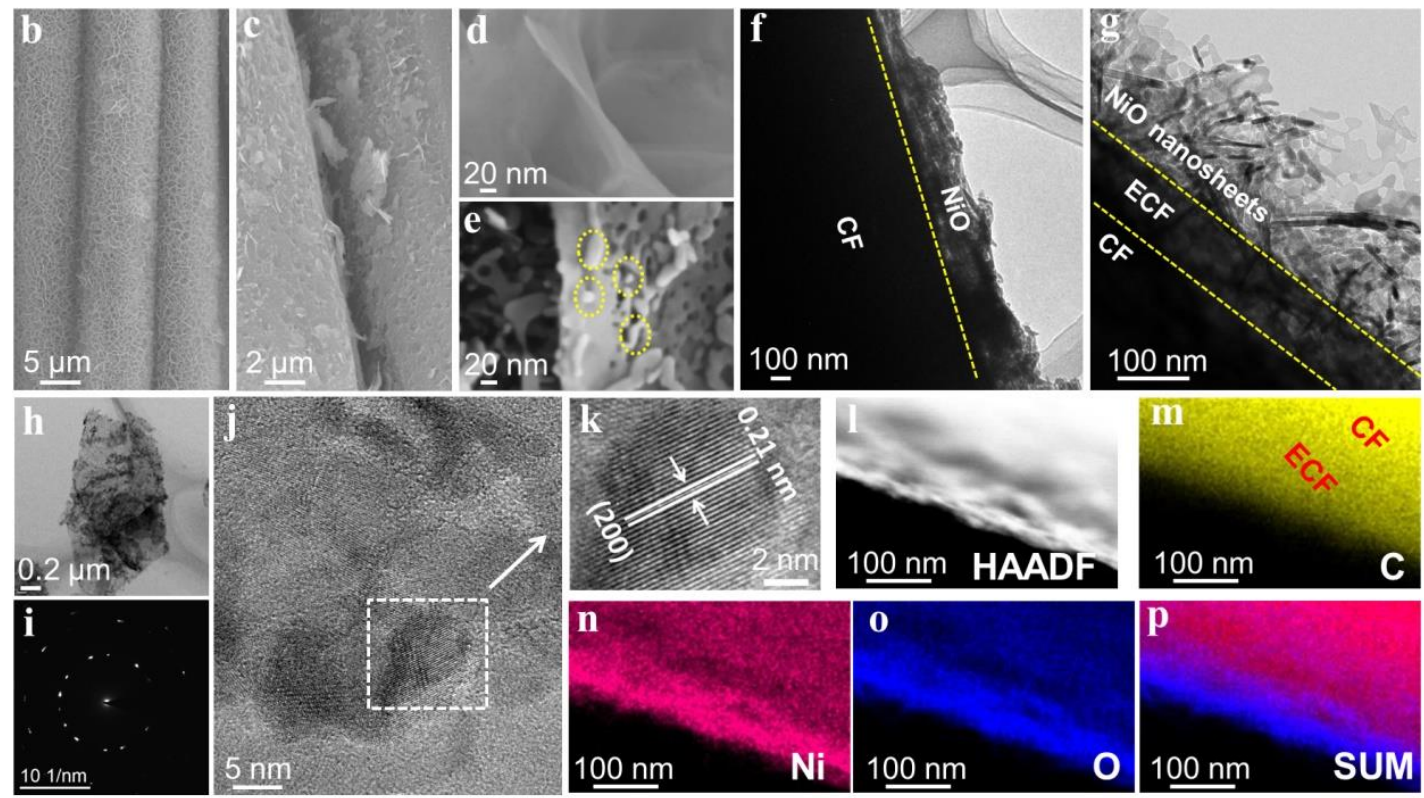

Fig. 1. Synthesis and Morphological characterization of the hybrids. a) Synthetic process of (i) $\mathrm{NiO}$ nanosheets on $\mathrm{CF} / \mathrm{ECF}(\mathrm{CF} / \mathrm{ECF} / \mathrm{NiO})$ and (ii) $\mathrm{CDs}$ on $\mathrm{CF} / \mathrm{ECF} / \mathrm{NiO}$ (CF/ECF/NiO/CD). b) SEM image of $\mathrm{CF} / \mathrm{ECF} / \mathrm{NiO} / \mathrm{CD}$. c) SEM image of $\mathrm{CF} / \mathrm{ECF} / \mathrm{NiO} / \mathrm{CD}$ showing the contact of $\mathrm{CC} @ \mathrm{EC}$ and $\mathrm{NiO}$ nanosheets. d) Magnified SEM image of $\mathrm{CF} / \mathrm{NiO}$ and e) Magnified SEM image of $\mathrm{CF} / \mathrm{ECF} / \mathrm{NiO} / \mathrm{CD}$ showing the CDs. TEM images of f) $\mathrm{CF} / \mathrm{NiO}$ and $\mathrm{g}$ ) $\mathrm{CF} / \mathrm{ECF} / \mathrm{NiO} / \mathrm{CD}$. h) Low magnification TEM image and i) corresponding SAED of $\mathrm{CF} / \mathrm{ECF} / \mathrm{NiO} / \mathrm{CD}$ nanosheets. j) HRTEM image of $\mathrm{NiO}$ nanosheet from $\mathrm{CF} / \mathrm{ECF} / \mathrm{NiO} / \mathrm{CD}$ showing $2 \mathrm{~d}$ lattices. k) HRTEM image of $\mathrm{CF} / \mathrm{ECF} / \mathrm{NiO} / \mathrm{CD}$ obtained from the dotted box in " $\mathrm{h}$ " showing lattice fringes of $0.21 \mathrm{~nm}$ corresponding to (200) phase of cubic NiO. 1-p) Elemental mapping of $\mathrm{CF} / \mathrm{ECF} / \mathrm{NiO} / \mathrm{CD}$ obtained from HRTEM image.

The porous and exfoliated surface of $\mathrm{CF} / \mathrm{ECF}$ can be clearly seen and identified in the Supporting Information, Figure S1a-b. We hypothesize that $\mathrm{CF} / \mathrm{ECF}$ should not only act as a current collector/substrate for the growth of 
$\mathrm{NiO}$ nanosheets (Figure 1a) but also to contribute to the capacity of the battery $[22,28]$. The weight of CF reduces after treatments (Figure S1d-g), indicating that the $\mathrm{CF} / \mathrm{ECF}$ current collector is lighter in weight than bare $\mathrm{CF}$, and does not lose its mechanical and flexible properties either (Figure S1c). According to scanning electron microscopy (SEM) analysis, uniform nanosheets of $\mathrm{NiO}$ were formed on the $\mathrm{CF} / \mathrm{ECF}$ current collector (Figure 1b). The fabrication process of $\mathrm{CF} / \mathrm{NiO}$ can be seen in Figure S2a. Similar nanosheets morphology was also formed on the CF current collector (Figure S2b). The NiO nanosheets adhered strictly to the surface of $\mathrm{CF} / \mathrm{ECF}$, indicating excellent binding interaction between the current collector and the $\mathrm{NiO}$ nanosheets (Figure 1c) [22], while the reverse remains the case for $\mathrm{CF} / \mathrm{NiO}$ (details in Figure S3). For $\mathrm{CF} / \mathrm{ECF} / \mathrm{NiO}$ and $\mathrm{CF} / \mathrm{NiO}$ samples, the surface of the nanosheets are very smooth (Figure 1d and S2b-c), respectively. After the insertion of CF/ECF/NiO sample to CDs solution via simple chemical bath process, CDs were deposited on the surface of the nanosheets (Figure 1e). The carbon dots were characterized using photoluminescence (PL) emission spectra as shown in Figure S4. The emission from the CDs continuously shifted to the higher wavelengths and the intensities of the shifted wavelength also varies. Such shift indicates emission of the surface-defects from the CDs. [29]

Transmission electron microscopy (TEM) studies were performed to investigate the core-triple layer architecture of $\mathrm{CF} / \mathrm{ECF} / \mathrm{NiO} / \mathrm{CD}$. According to Figure 1f, the nanosheets have no intimate interaction with the $\mathrm{CF}$ in the $\mathrm{CF} / \mathrm{NiO}$ sample. However, the TEM image of $\mathrm{CF} / \mathrm{ECF} / \mathrm{NiO} / \mathrm{CD}$ shows that the nanosheets are strictly bound and connected to the ECF (Figure 1g and enlarge image in Figure S5). The HRTEM images collected from $\mathrm{CF} / \mathrm{ECF} / \mathrm{NiO} / \mathrm{CD}$ 
nanosheets (Figure $1 \mathrm{~h}$ ) shows the $2 \mathrm{~d}$ lattices of $\mathrm{NiO}$ nanosheets (Figures $1 \mathrm{j}, \mathrm{S} 6 \mathrm{a}$ and $\mathrm{S} 6 \mathrm{c}$ ), while that of $\mathrm{CF} / \mathrm{NiO}$ also displays similar trend (Figure $\mathrm{S} 2 \mathrm{~d}-\mathrm{e}$ ). Selected Area Electron Diffraction (SAED) collected from the entire NiO nanosheets confirms the polycrystalline nature of the nanosheet (Figures 1i, S6b and S6d), while SAED collected from each different $\mathrm{NiO}$ nanoparticles shows the single crystalline nature of the nanoparticles (Figure S6e) with lattice fringes of $0.21 \mathrm{~nm}$ corresponding to the (200) phase of NiO (JCPDS N: 471049) (Figures 1k and S6f). Moreover, atomic number of CD is much less than the average atomic number of $\mathrm{NiO}$. According to the contrast mechanism in TEM, while the CD overlaps with $\mathrm{NiO}$, it should not be observable. Moreover, results from the energy dispersive X-ray spectrometry (EDS) mapping analysis also affirmed the layer by layer architecture of $\mathrm{CF} / \mathrm{ECF} / \mathrm{NiO} / \mathrm{CD}$ hybrid (Figure 11-p). The entire SEM, TEM and EDS results justified the formation of the $\mathrm{CF} / \mathrm{ECF} / \mathrm{NiO} / \mathrm{CD}$ nanosheets hybrid.

X-ray diffraction (XRD) pattern of $\mathrm{CF} / \mathrm{NiO}, \mathrm{CF} / \mathrm{ECF} / \mathrm{NiO}$ and $\mathrm{CF} / \mathrm{ECF} / \mathrm{NiO} / \mathrm{CD}$ are shown in Figure S7 and confirmed the presence of both carbon and $\mathrm{NiO}$ phases in all the samples. Compared to the pristine $\mathrm{CF} / \mathrm{NiO}$, the three major XRD phases of $\mathrm{NiO}$ shifted to the higher degree theta in both $\mathrm{CF} / \mathrm{ECF} / \mathrm{NiO}$ and $\mathrm{CF} / \mathrm{ECF} / \mathrm{NiO} / \mathrm{CD}$, suggesting electronic interaction between the current collector and NiO. [22] Additionally, the results obtained from the Raman spectra revealed that the ratio of the defect carbon (D band) and graphitic carbon (G-band) i.e. D:G value of $\mathrm{CF} / \mathrm{ECF} / \mathrm{NiO}$ is significantly higher than that of $\mathrm{CF} / \mathrm{NiO}$ due to the more defects and modification of the CF/ECF current collector (Figure S8) [22, 28]. Furthermore, Xray photo spectroscopy (XPS) analyses of the three samples affirmed the presence of $\mathrm{C}$, Ni and $\mathrm{O}$ (Figure $\mathrm{S} 9 \mathrm{a}$ ) but both $\mathrm{CF} / \mathrm{ECF} / \mathrm{NiO}$ and $\mathrm{CF} / \mathrm{ECF} / \mathrm{NiO} / \mathrm{CD}$ are 
characterized with $\mathrm{N}$ 1s peak confirming the presence of $\mathrm{N}$ in the complex hybrids originating from the formation of $\mathrm{CF} / \mathrm{ECF}$ substrate (Figure $\mathrm{S} 9 \mathrm{~b}$ ). The results obtained from the O 1s XPS spectra of the three samples show that apart from the characteristics peaks of lattice oxygen (Ni-O) and defect oxygen (defect $\mathrm{O}$ ), the $\mathrm{O} 1 \mathrm{~s}$ XPS spectra of $\mathrm{CF} / \mathrm{ECF} / \mathrm{NiO} / \mathrm{CD}$ possesses a new peak at $533.3 \mathrm{eV}$ assigned to $\mathrm{C}-\mathrm{OH}$ from the CDs $[30,31]$ and confirm the formation of CDs (Figure S9c). The entire XRD, Raman and XPS studies also affirmed the successful formation of

\section{$\mathrm{CF} / \mathrm{ECF} / \mathrm{NiO} / \mathrm{CD}$.}

\subsection{Lithium Storage Properties}

The lithium storage properties of $\mathrm{CF} / \mathrm{NiO}, \mathrm{CF} / \mathrm{ECF} / \mathrm{NiO}$ and $\mathrm{CF} / \mathrm{ECF} / \mathrm{NiO} / \mathrm{CD}$ were studied using them as working electrode and Li-foil as both counter and reference electrode. The $1^{\text {st }}-3^{\text {rd }}$ cyclic voltammetry $(\mathrm{CV})$ curves of the electrodes at scan rate of $0.1 \mathrm{mV} \mathrm{s}^{-1}$ were compared in Figure $\mathrm{S} 10$. The CV curves of the electrodes were used to discuss the mechanism of lithium intercalation. Owing to the capacity contribution from $\mathrm{CC}$ substrate, the three electrodes $(\mathrm{CF} / \mathrm{NiO}, \mathrm{CF} / \mathrm{ECF} / \mathrm{NiO}$ and $\mathrm{CF} / \mathrm{ECF} / \mathrm{NiO} / \mathrm{CD})$ displayed both $\mathrm{Li}$-ion conversion and insertion reactions from the $\mathrm{NiO}$ and $\mathrm{CF}$ or $\mathrm{CC} / \mathrm{ECF}$, respectively. Thus, the $\mathrm{Li}$-ion conversion and insertion reactions of $\mathrm{NiO}$ and $\mathrm{CF}$ are displayed in eq. 1 and 2 [17, 32];

$\mathrm{NiO}+2 \mathrm{Li}^{+}+2 \mathrm{e}^{-} \rightleftharpoons \mathrm{Ni}+\mathrm{Li}_{2} \mathrm{O}$

$\mathrm{C}_{6}+\mathrm{Li}^{+}+\mathrm{e}^{-} \rightleftharpoons \mathrm{LiC}_{6}$

In eq. (1), according to the $1^{\text {st }}$ electrochemical discharge cycle, elemental $\mathrm{Ni}$ and $\mathrm{Li}_{2} \mathrm{O}$ were formed indicating the conversion reaction from $\mathrm{NiO}$. [17, 32] In addition, both $\mathrm{CF}$ and $\mathrm{CF} / \mathrm{ECF}$ exhibits full insertion mechanism [22, 28]. For the $1^{\text {st }}-3^{\text {rd }}$ curve, the $\mathrm{CV}$ curve surface area and peak current densities of $\mathrm{CF} / \mathrm{ECF} / \mathrm{NiO} / \mathrm{CD}$ is the highest and strongest among the electrodes (Figure S11a-c) 
indicating higher electrochemical reactivity and capacity than both $\mathrm{CF} / \mathrm{NiO}$ and $\mathrm{CF} / \mathrm{ECF} / \mathrm{NiO}$.
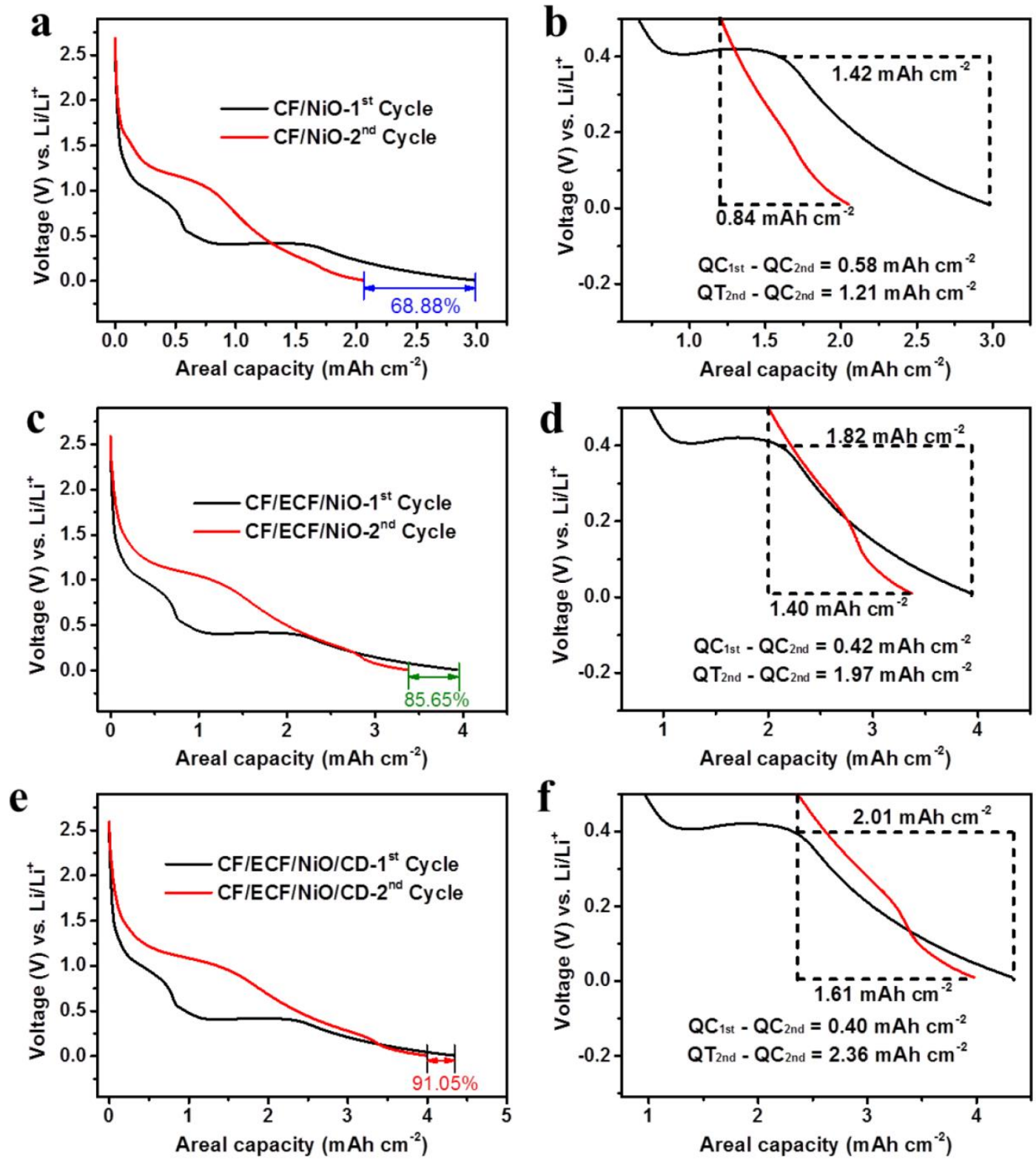

Fig. 2. Capacity contribution of $\mathrm{CF} / \mathrm{ECF}$ and $\mathrm{NiO}$. a) $1^{\text {st }}$ and $2^{\text {nd }}$ discharge profiles of $\mathrm{CF} / \mathrm{NiO}$. b) Discharge profiles between $0.5 \mathrm{~V}$ and $0.01 \mathrm{~V}$ showing the capacity contribution of $\mathrm{CF} / \mathrm{ECF} / \mathrm{NiO}$ electrode. c) $1^{\text {st }}$ and $2^{\text {nd }}$ discharge profiles of $\mathrm{CF} / \mathrm{ECF} / \mathrm{NiO}$. d) Discharge profiles between $0.5 \mathrm{~V}$ and $0.01 \mathrm{~V}$ showing the capacity contribution of $\mathrm{CF} / \mathrm{NiO}$ electrode. e) $1^{\text {st }}$ and $2^{\text {nd }}$ discharge profiles of $\mathrm{CF} / \mathrm{ECF} / \mathrm{NiO} / \mathrm{CD}$. f) Discharge profiles between $0.5 \mathrm{~V}$ and $0.01 \mathrm{~V}$ showing the capacity contribution of $\mathrm{CF} / \mathrm{ECF} / \mathrm{NiO} / \mathrm{CD}$. 
Moreover, the $2^{\text {nd }}$ and $3^{\text {rd }}$ cycle $\mathrm{CV}$ curves of $\mathrm{CF} / \mathrm{ECF} / \mathrm{NiO} / \mathrm{CD}$ electrodes are nearly the same suggesting high coulombic efficiency (CE). It should be pointed out that initial $\mathrm{CE}$ is one of the major problems of conversion reaction-based electrode materials owing to the formation of solid electrolyte interface (SEI) layer formation that causes large volume expansion and irreversible capacity loss [33-35]. Thus, the $\mathrm{CE}$ of $\mathrm{CF} / \mathrm{ECF} / \mathrm{NiO} / \mathrm{CD}$ is about $87 \%$ during the first electrochemical cycle and increases to nearly $98 \%$ after subsequent cycling (Figure S11a), which is higher than those of $\mathrm{CF} / \mathrm{ECF} / \mathrm{NiO}$ (Figure $\mathrm{S} 11 \mathrm{~b}$ ) and $\mathrm{CF} / \mathrm{NiO}$ (Figure S11c) confirming the $\mathrm{CV}$ results in Figure $\mathrm{S} 10$. Hence, the multihybrid $\mathrm{CF} / \mathrm{ECF} / \mathrm{NiO} / \mathrm{CD}$ system addresses the issue of poor initial CE.

Due to the higher electrochemical reactivity of $\mathrm{CF} / \mathrm{ECF} / \mathrm{NiO} / \mathrm{CD}$, the $1^{\text {st }}$ and $2^{\text {nd }}$ cycle discharge capacities of $\mathrm{CF} / \mathrm{ECF} / \mathrm{NiO} / \mathrm{CD}$ are 4.33 and $3.97 \mathrm{mAh} \mathrm{cm}^{-2}$ which are slightly higher than those of $\mathrm{CF} / \mathrm{ECF} / \mathrm{NiO}\left(3.93\right.$ and $\left.3.36 \mathrm{mAh} \mathrm{cm}^{-2}\right)$ and undoubtedly higher than that of $\mathrm{CF} / \mathrm{NiO}\left(2.97\right.$ and $2.05 \mathrm{mAh} \mathrm{cm}^{-2}$ ), respectively (Figures 2a,c,e and S11d-e). We believe that the higher capacity of $\mathrm{CF} / \mathrm{ECF} / \mathrm{NiO} / \mathrm{CD}$ and $\mathrm{CF} / \mathrm{ECF} / \mathrm{NiO}$ can be associated with the capacity contribution from $\mathrm{CF} / \mathrm{ECF}$. To verify this, firstly, the Li-ion storage properties of $\mathrm{CF}$ and $\mathrm{CF} / \mathrm{ECF}$ were also carried out to have detail information on the contribution of the carbon fiber. According to Figure $\mathrm{S} 12$, the storage performance of $\mathrm{CF} / \mathrm{ECF}$ is better than that of pristine $\mathrm{CF}$. The results suggest that $\mathrm{CF} / \mathrm{ECF}$ did not only displays superior performance than $\mathrm{CF}$ but will also contribute to the performance of $\mathrm{CF} / \mathrm{ECF}$-based electrodes than pristine $\mathrm{CF}$ based electrodes. Further analysis upon intercalation of $\mathrm{Li}$-ion into the $\mathrm{CF}$ and $\mathrm{CF} / \mathrm{ECF}$ below $0.5 \mathrm{~V}$ are studied using $1^{\text {st }}$ and $2^{\text {nd }}$ discharge processes because Li-ion are usually intercalated into CF matrix below $0.5 \mathrm{~V}$ [36-39]. The loss in the capacity contribution of carbon fiber current collectors (denoted as $\mathrm{QC}_{1 \mathrm{st}}-\mathrm{QC}_{2 \mathrm{nd}}$ ) in $\mathrm{CF} / \mathrm{NiO}$ is 
$0.58 \mathrm{mAh} \mathrm{cm}^{-2}$ (Figure 2b), which reduces to $0.42 \mathrm{mAh} \mathrm{cm}^{-2}$ in $\mathrm{CF} / \mathrm{ECF} / \mathrm{NiO}$ (Figure 2d) and $0.40 \mathrm{mAh} \mathrm{cm}^{-2}$ in $\mathrm{CF} / \mathrm{ECF} / \mathrm{NiO} / \mathrm{CD}$ (Figure 2f) indicating the $\mathrm{CF} / \mathrm{ECF}$ is highly resistant to losing much capacity upon SEI layer formation $[22,28,40]$. The results also imply that the capacity contributed from $\mathrm{NiO}$ nanosheets (denoted as $\mathrm{QT}_{2 \mathrm{nd}}-\mathrm{QC}_{2 \mathrm{nd}}$ ) increases from $1.21 \mathrm{mAh} \mathrm{cm}^{-2}$ in $\mathrm{CF} / \mathrm{NiO}$ to $1.97 \mathrm{mAh} \mathrm{cm}^{-2}$ in $\mathrm{CF} / \mathrm{ECF} / \mathrm{NiO}$ and $2.36 \mathrm{mAh} \mathrm{cm}^{-2}$ in $\mathrm{CF} / \mathrm{ECF} / \mathrm{NiO} / \mathrm{CD}$. Despite both $\mathrm{CF} / \mathrm{ECF} / \mathrm{NiO}$ and $\mathrm{CF} / \mathrm{ECF} / \mathrm{NiO} / \mathrm{CD}$ electrodes benefit from the capacity contribution from $\mathrm{CF} / \mathrm{ECF}$ current collectors, the areal capacity of $\mathrm{CF} / \mathrm{ECF} / \mathrm{NiO} / \mathrm{CD}$ tends to be higher than $\mathrm{CF} / \mathrm{ECF} / \mathrm{NiO}$, which can be attributed to the coating of CDs on the nanosheets surface. As it is well known that most TMOs exhibits poor conductivity and stability [6, 41], the coating of $\mathrm{CDs}$ could not only be used to enhance the conductivity of $\mathrm{NiO}$ nanosheets but also as a stabilizer for the entire multihybrid system. [23, 42] This further identifies that coating of CDs could enhance the CE and capacity of $\mathrm{CF} / \mathrm{ECF} / \mathrm{NiO} / \mathrm{CD}$ and also helpful in enhancing its conductivity and stability. Hence, the capacity loss after the $2^{\text {nd }}$ discharge cycle is $91 \%$ for $\mathrm{CF} / \mathrm{ECF} / \mathrm{NiO} / \mathrm{CD}$ electrode (Figure 2e) and unquestionably superior to those of $\mathrm{CF} / \mathrm{NiO}$ (69\%, Figure 2a) and $\mathrm{CF} / \mathrm{ECF} / \mathrm{NiO}$ (86\%, Figure 2c).

High-rate capability and excellent stability are crucial factors towards achieving high areal capacity LIBs. According to Figure $3 \mathrm{a}, \mathrm{CF} / \mathrm{ECF} / \mathrm{NiO} / \mathrm{CD}$ displayed continuous superiority in performance over $\mathrm{CF} / \mathrm{NiO}$ and $\mathrm{CF} / \mathrm{ECF} / \mathrm{NiO}$ at different current densities ranging from $0.25 \mathrm{~mA} \mathrm{~cm}^{-2}$ to $6.0 \mathrm{~mA} \mathrm{~cm}{ }^{-2}$. Both $\mathrm{CF} / \mathrm{ECF} / \mathrm{NiO}$ and $\mathrm{CF} / \mathrm{ECF} / \mathrm{NiO} / \mathrm{CD}$ display nearly the same capacity at current density of $0.25 \mathrm{~mA} \mathrm{~cm}^{-2}$. However, $\mathrm{CF} / \mathrm{ECF} / \mathrm{NiO} / \mathrm{CD}$ delivers a high areal capacity of $2.61 \mathrm{mAh} \mathrm{cm}^{-2}$ at current density of $6.0 \mathrm{~mA} \mathrm{~cm}^{-2}$, which outshine that those of $\mathrm{CF} / \mathrm{ECF} / \mathrm{NiO}\left(1.25 \mathrm{mAh} \mathrm{cm}^{-2}\right)$, $\mathrm{CF} / \mathrm{NiO}\left(0.24 \mathrm{mAh} \mathrm{cm}^{-2}\right)$ and recently reported areal capacity-based electrodes [11, 
20, 43]. The excellent rate performance of $\mathrm{CF} / \mathrm{ECF} / \mathrm{NiO} / \mathrm{CD}$ is associated with enhanced and rapid kinetics owing to the coating of the CDs that could act as useful stabilizer.
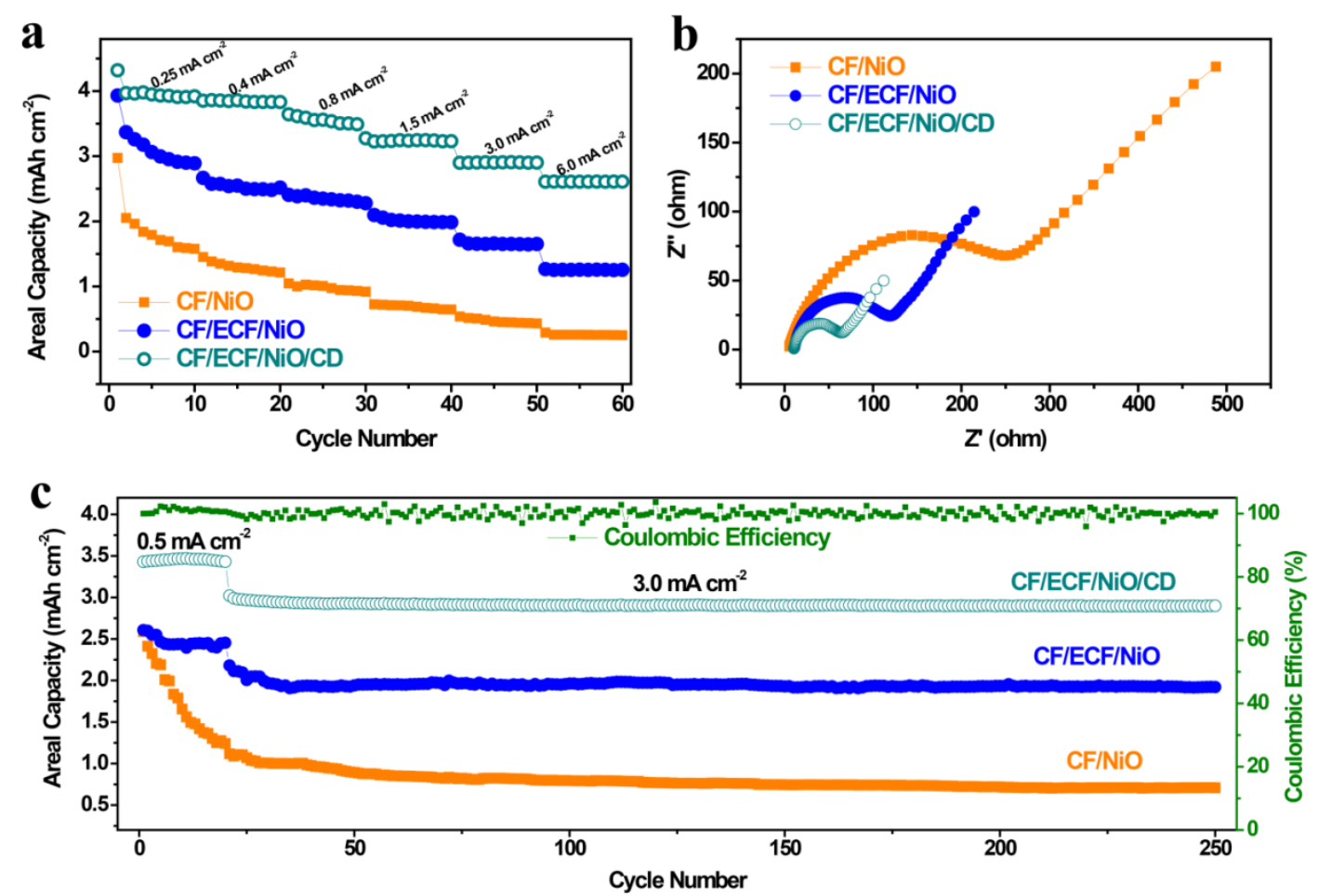

Fig. 3. Lithium storage Properties. a) Rate capability, b) Nyquist plot and c) cyclic stability of $\mathrm{CF} / \mathrm{NiO}, \mathrm{CF} / \mathrm{ECF} / \mathrm{NiO}$ and $\mathrm{CF} / \mathrm{ECF} / \mathrm{NiO} / \mathrm{CD}$ electrodes.

The electrochemical impedance spectroscopy (EIS) analysis provide further information on the kinetics of the electrodes revealing that the semi-circle in the Nyquist plots of the electrodes represent the charge transfer resistance $\left(R_{c t}\right.$, i.e. the smaller the semi-circle, the better the kinetics). Thus, $\mathrm{CF} / \mathrm{ECF} / \mathrm{NiO} / \mathrm{CD}$ cell displayed the smallest $\mathrm{R}_{\mathrm{ct}}(64.5 \Omega)$ compared to $\mathrm{CF} / \mathrm{ECF} / \mathrm{NiO}(119.1 \Omega)$ and $\mathrm{CF} / \mathrm{NiO}(255.1 \Omega)$ (Figure 3b) suggesting superior kinetics of $\mathrm{CF} / \mathrm{ECF} / \mathrm{NiO} / \mathrm{CD}$ over its counterparts. The EIS results additionally affirm that CDs coating could be the reasons for high-rate performance in $\mathrm{CF} / \mathrm{ECF} / \mathrm{NiO} / \mathrm{CD}$ electrode. Furthermore, $\mathrm{CF} / \mathrm{ECF} / \mathrm{NiO} / \mathrm{CD}$ electrode continues to display outstanding stability up to 250 cycles at current density of 3.0 
$\mathrm{mA} \mathrm{cm} \mathrm{c}^{-2}$ retaining an areal capacity of $2.91 \mathrm{mAh} \mathrm{cm}^{-2}$ and outperformed those of $\mathrm{CF} / \mathrm{ECF} / \mathrm{NiO}\left(1.92 \mathrm{mAh} \mathrm{cm}^{-2}\right)$ and $\mathrm{CF} / \mathrm{NiO}\left(0.71 \mathrm{mAh} \mathrm{cm}^{-2}\right)$ (Figure $3 \mathrm{c}$ ). One important factor is that compared to $\mathrm{CF} / \mathrm{NiO}$ (displaying continuous and drastic capacity deterioration between the $1^{\text {st }}$ and $50^{\text {th }}$ electrochemical cycling) and $\mathrm{CF} / \mathrm{ECF} / \mathrm{NiO}$ (showing slow capacity deterioration between the $1^{\text {st }}$ and $50^{\text {th }}$ electrochemical cycling), $\mathrm{CF} / \mathrm{ECF} / \mathrm{NiO} / \mathrm{CD}$ could achieve no capacity deterioration upon the entire electrochemical stability cycles. By comparing the SEM morphological images of both $\mathrm{CF} / \mathrm{NiO}$ and $\mathrm{CF} / \mathrm{ECF} / \mathrm{NiO} / \mathrm{CD}$ after stability test, the nanosheets morphology of $\mathrm{NiO}$ can still be maintained justifying the excellent stability of $\mathrm{CF} / \mathrm{ECF} / \mathrm{NiO} / \mathrm{CD}$ electrode (Figure $\mathrm{S} 13 \mathrm{a}$ ), while those of $\mathrm{CF} / \mathrm{NiO}$ have been destroyed (Figure S13b). These results also confirms that the $\mathrm{NiO}$ nanosheets have intimate interaction with the $\mathrm{CF} / \mathrm{ECF}$ but have little or no intimate interaction with the CF. Likewise, there exists less variation in the kinetics of $\mathrm{CF} / \mathrm{ECF} / \mathrm{NiO} / \mathrm{CD}$ electrode as well (Figure S14). Hence, the excellent Li-storage performance of $\mathrm{CF} / \mathrm{ECF} / \mathrm{NiO} / \mathrm{CD}$ electrode can not only be credited to the capacity contribution and excellent conductivity of the $\mathrm{CF} / \mathrm{ECF}$ current collector but also the introduction of efficient CDs stabilizer.

\subsection{In situ Raman Study}

To have further insight on the capacity contribution from $\mathrm{CF} / \mathrm{ECF}$ towards achieving high areal capacity LIBs, in situ Raman spectra analysis was performed for $\mathrm{CF} / \mathrm{NiO}$ and $\mathrm{CF} / \mathrm{ECF} / \mathrm{NiO} / \mathrm{CD}$ cells during the $2^{\text {nd }}$ discharge cycle. The in situ Raman spectra analysis could be simultaneously used to study the degradation mechanism for the discharge capacity of $\mathrm{CF} / \mathrm{NiO}$. Firstly, according to Figures 2 and 3, electrochemical analyses have shown that the $\mathrm{CF} / \mathrm{ECF} / \mathrm{NiO}$ and $\mathrm{CF} / \mathrm{ECF} / \mathrm{NiO} / \mathrm{CD}$ shows better performance than $\mathrm{CF} / \mathrm{NiO}$. 

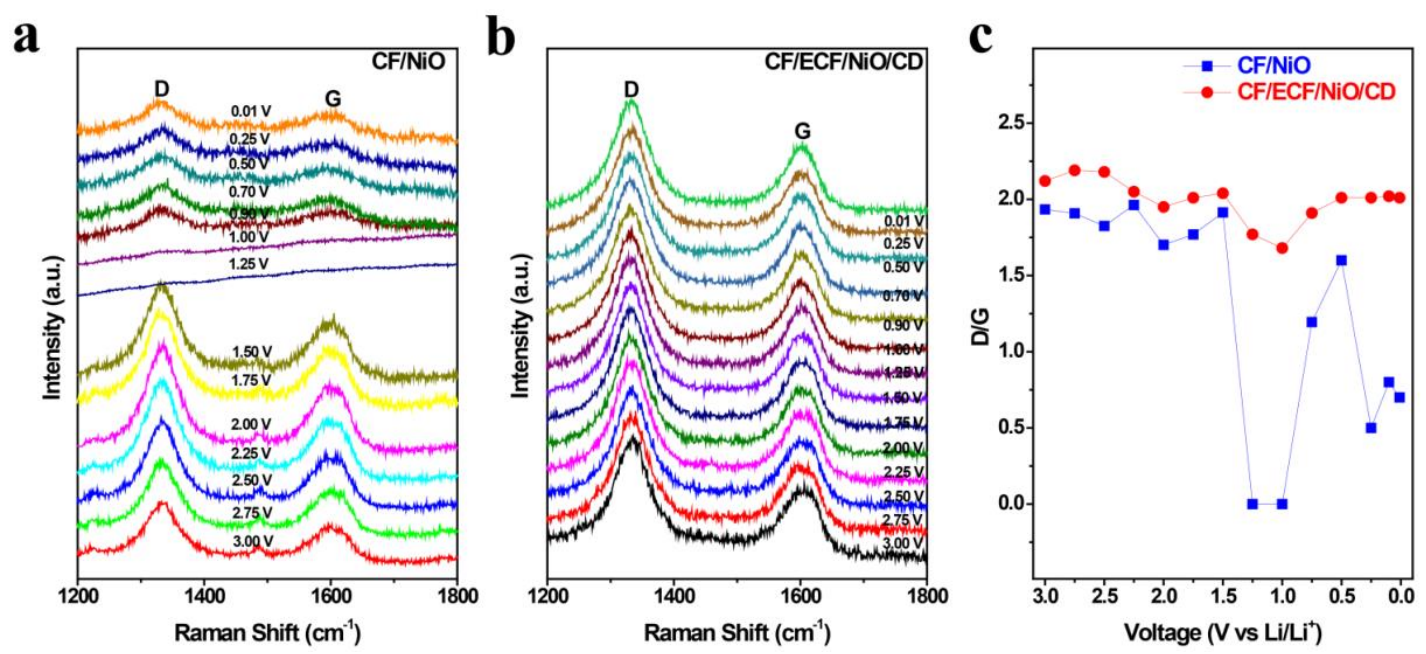

Fig. 4. In-situ Raman spectra of a) $\mathrm{CF} / \mathrm{NiO}$ and b) $\mathrm{CF} / \mathrm{ECF} / \mathrm{NiO} / \mathrm{CD}$ at different intercalated voltages. c) Plot of the ID/IG vs. intercalated voltages of $\mathrm{CF} / \mathrm{NiO}$ and $\mathrm{CF} / \mathrm{ECF} / \mathrm{NiO} / \mathrm{CD}$ cells.

The inferior performance of $\mathrm{CF} / \mathrm{NiO}$ can be attributed to the little or no capacity from the CF current collector electrode. Raman analysis is one of the most vital parameter to study the variation in the D and G bands of carbon materials [22]. Hence, we utilized Raman spectra analysis to study the variation of D and G bands during $\mathrm{Li}$-ion reaction with the both $\mathrm{CF} / \mathrm{NiO}$ and $\mathrm{CF} / \mathrm{ECF} / \mathrm{NiO} / \mathrm{CD}$. Figure $4 \mathrm{a}$ and $4 \mathrm{~b}$ display the Raman spectra of $\mathrm{CF} / \mathrm{NiO}$ and $\mathrm{CF} / \mathrm{ECF} / \mathrm{NiO} / \mathrm{CD}$ at different $\mathrm{Li}$-ion insertion voltages ranging from $3.0 \mathrm{~V}$ to $0.01 \mathrm{~V}$, respectively. The $\mathrm{D}: \mathrm{G}$ value collected at each voltage were plotted against the corresponding voltages. Figure 4c shows that upon $\mathrm{Li}$-ion intercalation into both $\mathrm{CF} / \mathrm{NiO}$ and $\mathrm{CF} / \mathrm{ECF} / \mathrm{NiO} / \mathrm{CD}$ between 3.0 and $1.5 \mathrm{~V}$, the voltage-D:G plots almost remain the same for both cells (approximately 2.0). Between $1.5 \mathrm{~V}$ and $1.0 \mathrm{~V}$, the $\mathrm{D}: \mathrm{G}$ values are zero for $\mathrm{CF} / \mathrm{NiO}$ cell due to $\mathrm{Li}$-ion intercalation into the $\mathrm{NiO}$ structure. This indicates that the $\mathrm{CF}$ displays little or less contribution to the $\mathrm{Li}$-storage process of $\mathrm{CF} / \mathrm{NiO}$. However, the $\mathrm{D}: \mathrm{G}$ values at these voltages for $\mathrm{CF} / \mathrm{ECF} / \mathrm{NiO} / \mathrm{CD}$ slightly reduces (1.77 and 1.68 ) indicating that $\mathrm{CF} / \mathrm{ECF}$ greatly contributed to the Li-storage process of 
$\mathrm{CF} / \mathrm{ECF} / \mathrm{NiO} / \mathrm{CD}$ anode and also suggesting the interaction between $\mathrm{CF} / \mathrm{ECF}$ and $\mathrm{NiO}$. Our previous work shows that the $\mathrm{D}: \mathrm{G}$ value during Li-ion intercalation at $1.0 \mathrm{~V}$ is also zero [22] and we could relate such phenomenon to the slight loss in the cell capacity due to the poor conductivity and stability of such TMO. However, we address such phenomenon in this present work by coating CDs on the nanostructure interface to relief the poor conductivity and stability of $\mathrm{NiO}$, which could reduce capacity loss, improve electrochemical reactivity and enhance CE towards achieving highly stable and highly conductive monolithic electrode [44]. As the discharge process proceeds to $0.5 \mathrm{~V}$ and below, the $\mathrm{D}: \mathrm{G}$ values of $\mathrm{CF} / \mathrm{ECF} / \mathrm{NiO} / \mathrm{CD}$ increases and maintains the same values with those of high voltage region indicating capacity contribution from $\mathrm{CF} / \mathrm{ECF}$ substrate. However, reverse is the case for $\mathrm{CF} / \mathrm{NiO}$ because the D:G value reduces to 0.4 upon complete discharging process, which can be observed from the weak D and G peaks according Figure 4a compared to that of $\mathrm{CF} / \mathrm{ECF} / \mathrm{NiO} / \mathrm{CD}$. Low $\mathrm{D}: \mathrm{G}$ value at low discharge voltage in $\mathrm{CF} / \mathrm{NiO}$ cell indicates that intercalation of Li-ion into the CF cavity shows less capacity contribution to the entire electrode. Hence, the in situ Raman spectra results confirmed CF/ECF contributed to the high areal capacity of $\mathrm{CF} / \mathrm{ECF} / \mathrm{NiO} / \mathrm{CD}$ electrode.

\subsection{Electronic Interaction Study}

The synergistic effect between $\mathrm{CF} / \mathrm{ECF}$ and $\mathrm{NiO}$ coupled with coating of CDs plays a crucial part on the excellent $\mathrm{Li}$ storage performance of $\mathrm{CF} / \mathrm{ECF} / \mathrm{NiO} / \mathrm{CD}$. Such synergistic effects have been proven to originate from the change in the electronic structure within the hybrids during the electrode design $[11,22]$. To confirm this, XPS spectra analyses were employed for further verification. According to C 1s XPS spectra, the $\mathrm{C}-\mathrm{C}$ bond of both $\mathrm{CF} / \mathrm{ECF} / \mathrm{NiO}$ and $\mathrm{CF} / \mathrm{ECF} / \mathrm{NiO} / \mathrm{CD}$ exhibited a positive binding energy shift (Figure 5a), while the entire Ni 2p XPS spectra exhibited a 
negative binding energy shift (Figure $5 b$ ) and $\mathrm{CF} / \mathrm{ECF} / \mathrm{NiO} / \mathrm{CD}$ is characterized with the most positive and negative shifts.
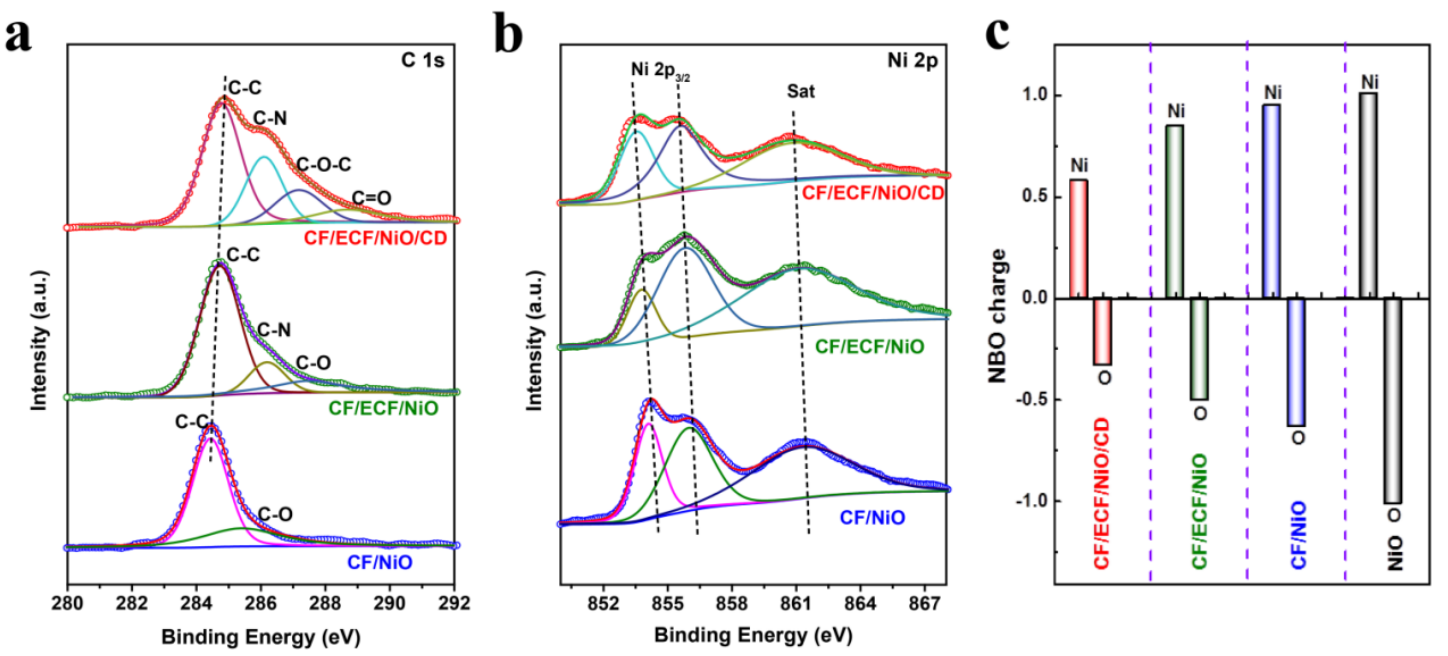

Fig. 5. Electronic interaction characterization. a) C 1s and b) Ni 2p XPS spectra of $\mathrm{CF} / \mathrm{NiO}, \mathrm{CF} / \mathrm{ECF} / \mathrm{NiO}$ and $\mathrm{CF} / \mathrm{ECF} / \mathrm{NiO} / \mathrm{CD}$. c) $\mathrm{NBO}$ Charge density redistributions on $\mathrm{CF} / \mathrm{NiO}, \mathrm{CF} / \mathrm{ECF} / \mathrm{NiO}$ and $\mathrm{CF} / \mathrm{ECF} / \mathrm{NiO} / \mathrm{CD}$ obtained from the theoretical calculations.

Such shifts in the XPS spectra of $\mathrm{C}$ and Ni imply a change in the electronic configuration of the samples upon continuous hybridization and created strongest electronic interaction in $\mathrm{CF} / \mathrm{ECF} / \mathrm{NiO} / \mathrm{CD}$ when compared with $\mathrm{CF} / \mathrm{NiO}$ and $\mathrm{CF} / \mathrm{ECF} / \mathrm{NiO}$. Moreover, it was noted that the characteristic Raman peak around 534 $\mathrm{cm}^{-1}$, which is assigned to the Raman band of NiO [17], as well as those of D and G bands show red-shifts (Figure S8) indicating that the state of bonding in the doublehybrid samples changes due to electronic interactions between $\mathrm{CF} / \mathrm{ECF}, \mathrm{NiO}$ and $\mathrm{CD}$ [45].

\subsection{Natural Bonding Orbital (NBO) Charge Distribution}

The change in the electronic structure and interaction among the samples can further be verified by the variation in the charge distribution of the samples, which can be determined by Density functional theory (DFT) calculations. NiO was also introduced 
for basic comparisons. The structure model for the DFT calculations of CF, ECF, NiO, $\mathrm{CF} / \mathrm{NiO}, \mathrm{CF} / \mathrm{ECF} / \mathrm{NiO}$ and $\mathrm{CF} / \mathrm{ECF} / \mathrm{NiO} / \mathrm{CD}$ can be found in Figure S15a-f, respectively. The natural bonding orbital (NBO) distribution of the samples is displayed in Figure 5c and the covalent bonding between the $\mathrm{C}$ and $\mathrm{O}$ functional groups of $\mathrm{CF} / \mathrm{ECF}$ and $\mathrm{NiO}$ is clearly identified in Figure S16. In the electronic structure of $\mathrm{CF} / \mathrm{ECF} / \mathrm{NiO} / \mathrm{CD}$, the charges on both $\mathrm{Ni}$ and $\mathrm{O}$ becomes less electropositive and less electronegative, respectively (Figure 5c), while the charge on C becomes more electropositive (Figure S17), and reverse is the case for other samples, meaning that the electropositivity and electronegativity in $\mathrm{Ni}$ and $\mathrm{O}$ increases in the order of $\mathrm{CF} / \mathrm{ECF} / \mathrm{NiO} / \mathrm{CD}<\mathrm{CF} / \mathrm{ECF} / \mathrm{NiO}<\mathrm{CF} / \mathrm{NiO}<\mathrm{NiO}$ and the electropositivity in $\mathrm{C}$ decreases in the order of $\mathrm{CF} / \mathrm{ECF} / \mathrm{NiO} / \mathrm{CD}>\mathrm{CF} / \mathrm{ECF} / \mathrm{NiO}>$ $\mathrm{CF} / \mathrm{NiO}$. These results is in accordance with our XPS results further affirming that there exists stronger electronic interaction between each materials in $\mathrm{CF} / \mathrm{ECF} / \mathrm{NiO} / \mathrm{CD}$ and the strongest electronic interaction is in the order of $\mathrm{CF} / \mathrm{ECF} / \mathrm{NiO} / \mathrm{CD}>$ $\mathrm{CF} / \mathrm{ECF} / \mathrm{NiO}>\mathrm{CF} / \mathrm{NiO}>\mathrm{NiO}$. Hence, such interaction is responsible for the rapid Li-ion transportation pathway and favorable kinetics in $\mathrm{CF} / \mathrm{ECF} / \mathrm{NiO} / \mathrm{CD}$ electrode system.

\section{Discussion}

\subsection{Electron Charge Density and Adsorption Capability}

In order to study the adsorption behavior of $\mathrm{Li}$ on $\mathrm{CF} / \mathrm{NiO}, \mathrm{CF} / \mathrm{ECF} / \mathrm{NiO}$ and $\mathrm{CF} / \mathrm{ECF} / \mathrm{NiO} / \mathrm{CD}$ hybrids, the difference in the electron density for Li-ion on these hybrids were studied using DFT calculations. Different from $\mathrm{CF} / \mathrm{NiO}$ hybrid, the slices on oxygen surface in both $\mathrm{CF} / \mathrm{ECF} / \mathrm{NiO}$ and $\mathrm{CF} / \mathrm{ECF} / \mathrm{NiO} / \mathrm{CD}$ show 
accumulation of electrons around the ECF, indicating stronger charge transfer than those of $\mathrm{CF} / \mathrm{NiO}$ (Figure 6a-c).

a
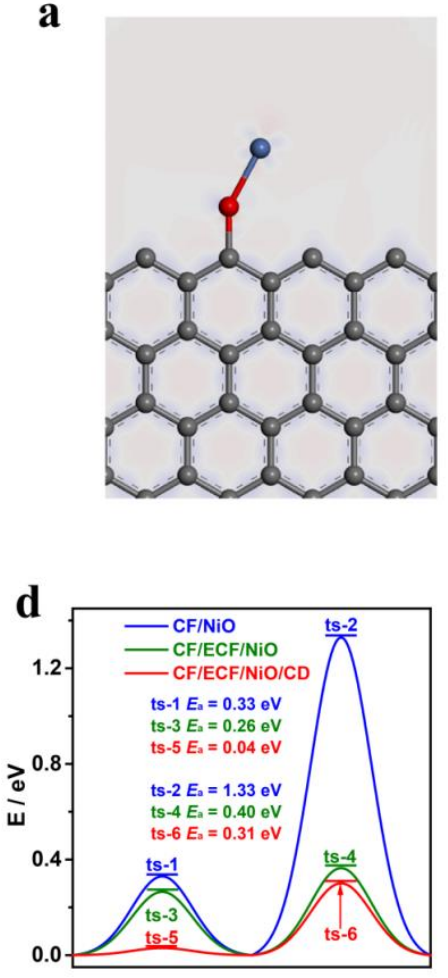

b
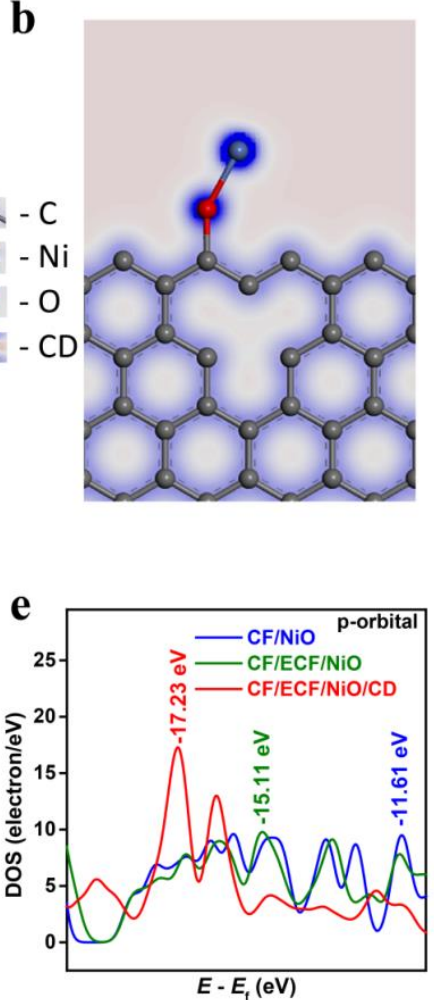

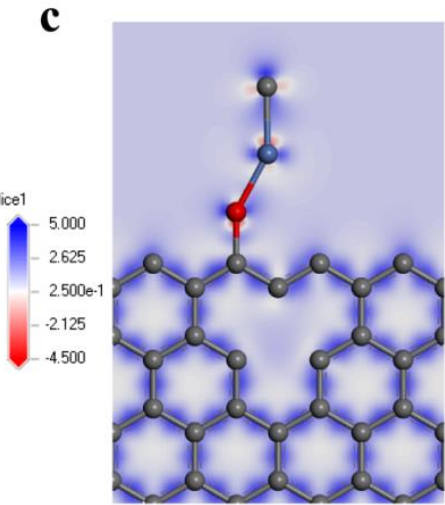

f

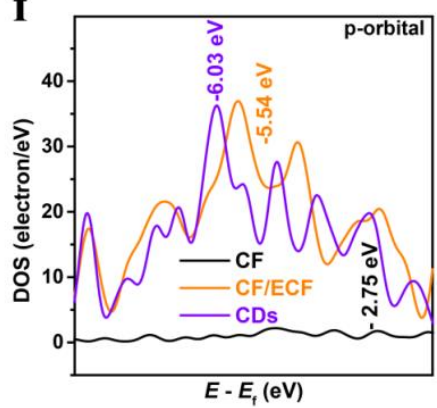

Fig. 6. Mechanism and Theoretical Characterization. Differences of electron charge density for $\mathrm{Li}$ on a) $\mathrm{CF} / \mathrm{NiO}$, b) $\mathrm{CF} / \mathrm{ECF} / \mathrm{NiO}$ and c) $\mathrm{CF} / \mathrm{ECF} / \mathrm{NiO} / \mathrm{CD}$ electrodes. d) Gibb's free adsorption energy $(\Delta \mathrm{G})$ profile of Li-ion intercalation via $\mathrm{CF} / \mathrm{NiO}$, $\mathrm{CF} / \mathrm{ECF} / \mathrm{NiO}$ and $\mathrm{CF} / \mathrm{ECF} / \mathrm{NiO} / \mathrm{CD}$. e) DOS plots of $\mathrm{CF} / \mathrm{NiO}, \mathrm{CF} / \mathrm{ECF} / \mathrm{NiO}$ and $\mathrm{CF} / \mathrm{ECF} / \mathrm{NiO} / \mathrm{CD}$ and their corresponding p-bands. f) DOS plots of $\mathrm{CF}, \mathrm{CF} / \mathrm{ECF}$ and $\mathrm{CD}$ and their corresponding $\mathrm{p}$-bands.

After $\mathrm{CD}$ introduction, the slice on $\mathrm{CD}$ surface in the $\mathrm{CF} / \mathrm{ECF} / \mathrm{NiO} / \mathrm{CD}$ shows more charge accumulation around the Ni (Figure 6c), implying an enhanced binding energy between the adsorbates and the hybrid surface allowing $\mathrm{CF} / \mathrm{ECF} / \mathrm{NiO} / \mathrm{CD}$ to exhibit the strongest charge transfer and adsorption of Li-ion [46]. During Li-ion transportation within the hybrids, the optimal Gibbs free energy change $\left(\Delta \mathrm{G}_{\mathrm{Li}^{*}}\right)$ requires for the Li-ion discharge process were determined. The closer the $\Delta \mathrm{G}_{\mathrm{Li}^{*}}\left(E_{\mathrm{a}}\right.$, $\mathrm{eV})$ value to zero $(0 \mathrm{eV})$, the faster the transportation of Li-ion and kinetics [47, 48]. 
The simulations for $\mathrm{Li}$-ion intercalation in $\mathrm{CF} / \mathrm{NiO}, \mathrm{CF} / \mathrm{ECF} / \mathrm{NiO}$ and $\mathrm{CF} / \mathrm{ECF} / \mathrm{NiO} / \mathrm{CD}$ are depicted in Figure S18a-c, respectively. According to Figure 6d, there are two peak regions representing the $\Delta \mathrm{G}_{\mathrm{Li}^{*}}$ for both $\mathrm{NiO}$ and $\mathrm{C}$. The $\Delta \mathrm{G}_{\mathrm{Li}^{*}}$ for Li-ion intercalation into NiO-region (denoted as ts-1/3/5 for the 3 electrodes, respectively) reduces in the order of $\mathrm{CF} / \mathrm{ECF} / \mathrm{NiO} / \mathrm{CD}(0.04 \mathrm{eV})<\mathrm{CF} / \mathrm{ECF} / \mathrm{NiO}(0.26$ $\mathrm{eV})<\mathrm{CF} / \mathrm{NiO}(0.33 \mathrm{eV})$ (Figure $6 \mathrm{~d})$. This result implies that the coating of CDs on $\mathrm{NiO}$ allows $\mathrm{CF} / \mathrm{ECF} / \mathrm{NiO} / \mathrm{CD}$ to attract less adsorption energy leading to enhance rapid transportation of Li-ion and high capacity. Additionally, the $\Delta \mathrm{G}_{\mathrm{Li}^{*}}$ for Li-ion intercalation into C-region (denoted as ts-2/4/6 for the 3 electrodes, respectively) also reduces in the order of $\mathrm{CF} / \mathrm{ECF} / \mathrm{NiO} / \mathrm{CD}(0.31 \mathrm{eV})<\mathrm{CF} / \mathrm{ECF} / \mathrm{NiO}(0.40 \mathrm{eV})<$ $\mathrm{CF} / \mathrm{NiO}(1.33 \mathrm{eV})$ (Figure 6d). It can be observed that the $\Delta \mathrm{G}_{\mathrm{Li}^{*}}$ values of Li-ion intercalation into $\mathrm{C}$ are higher than that of $\mathrm{NiO}$, suggesting the lower capacity contribution from C-region compared to that of NiO-region. Moreover, both $\mathrm{CF} / \mathrm{ECF} / \mathrm{NiO} / \mathrm{CD}$ and $\mathrm{CF} / \mathrm{ECF} / \mathrm{NiO}$ requires much lesser free energy due to the excellent properties of $\mathrm{CF} / \mathrm{ECF}$ compared to bare $\mathrm{CF}$ and its derivative $(\mathrm{CF} / \mathrm{NiO})$.

\subsection{Density of States (DOS)}

The density of states (DOS) of Li-ion transportation near the Fermi level $\left(E_{\mathrm{f}}\right)$ that majorly originates from the p-band adsorption energy state [49], were further analyzed to solidify the electronic interaction between the CF/ECF and the active material NiO (Figure S19). According to Figure S20, the d-orbital center relative to $E_{\mathrm{f}}$ are calculated to be in the order of $\mathrm{CF} / \mathrm{NiO}(-8.77 \mathrm{eV})>\mathrm{CF} / \mathrm{ECF} / \mathrm{NiO}(-7.43 \mathrm{eV})>$ $\mathrm{CF} / \mathrm{ECF} / \mathrm{NiO} / \mathrm{CD}(-5.13 \mathrm{eV})$. However, the p-orbital center relative $E_{\mathrm{f}}$ are determined to be in the order of $\mathrm{CF} / \mathrm{ECF} / \mathrm{NiO} / \mathrm{CD}(-17.23 \mathrm{eV})>\mathrm{CF} / \mathrm{ECF} / \mathrm{NiO}(-15.11 \mathrm{eV})>$ $\mathrm{CF} / \mathrm{NiO}(-11.61 \mathrm{eV})$ (Figure 6e). From these results, we deduced that the introduction of $\mathrm{CDs}$ allows the p-band center of $\mathrm{CF} / \mathrm{ECF} / \mathrm{NiO} / \mathrm{CD}$ to be far away from $E_{\mathrm{f}}$, 
suggesting strong adhesiveness of bonding states and strengthening of the electronic interaction within the $\mathrm{CF} / \mathrm{ECF} / \mathrm{NiO} / \mathrm{CD}$ matrix [49]. Impressively, as the relationship between the d-orbital center and $E_{\mathrm{f}}$ of $\mathrm{CF}, \mathrm{CF} / \mathrm{ECF}$ and $\mathrm{CDs}$ are zero (Figure S21) the p-orbital center of $\mathrm{CF}, \mathrm{CF} / \mathrm{ECF}$ and $\mathrm{CDs}$ relative to $E_{\mathrm{f}}$ are derived to be $-2.75 \mathrm{eV}$, $5.54 \mathrm{eV}$ and $-6.03 \mathrm{eV}$, respectively (Figure 6f), showing that $\mathrm{CF} / \mathrm{ECF}$ and $\mathrm{CD}$ are farther from the $E_{\mathrm{f}}$ than $\mathrm{CF}$. Such phenomenon further explains the reason why $\mathrm{CF} / \mathrm{ECF} / \mathrm{NiO} / \mathrm{CD}$, designed with both $\mathrm{CF} / \mathrm{ECF}$ and $\mathrm{CD}$, could exhibit the farthest $\mathrm{p}$ orbital center relative to $E_{\mathrm{f}}$. Hence, the excellent $\mathrm{Li}$ storage performance of $\mathrm{CF} / \mathrm{ECF} / \mathrm{NiO} / \mathrm{CD}$ emanates from the p-orbital shift, which grants the modulation of the electrochemical behaviour of $\mathrm{NiO}$ to be high areal capacity anode for LIBs.

\subsection{Mechanism}

The schematic representation of the Li-ion transfer depicted in Scheme 1 explained the proposed mechanism for lithium storage capacity enhancement.

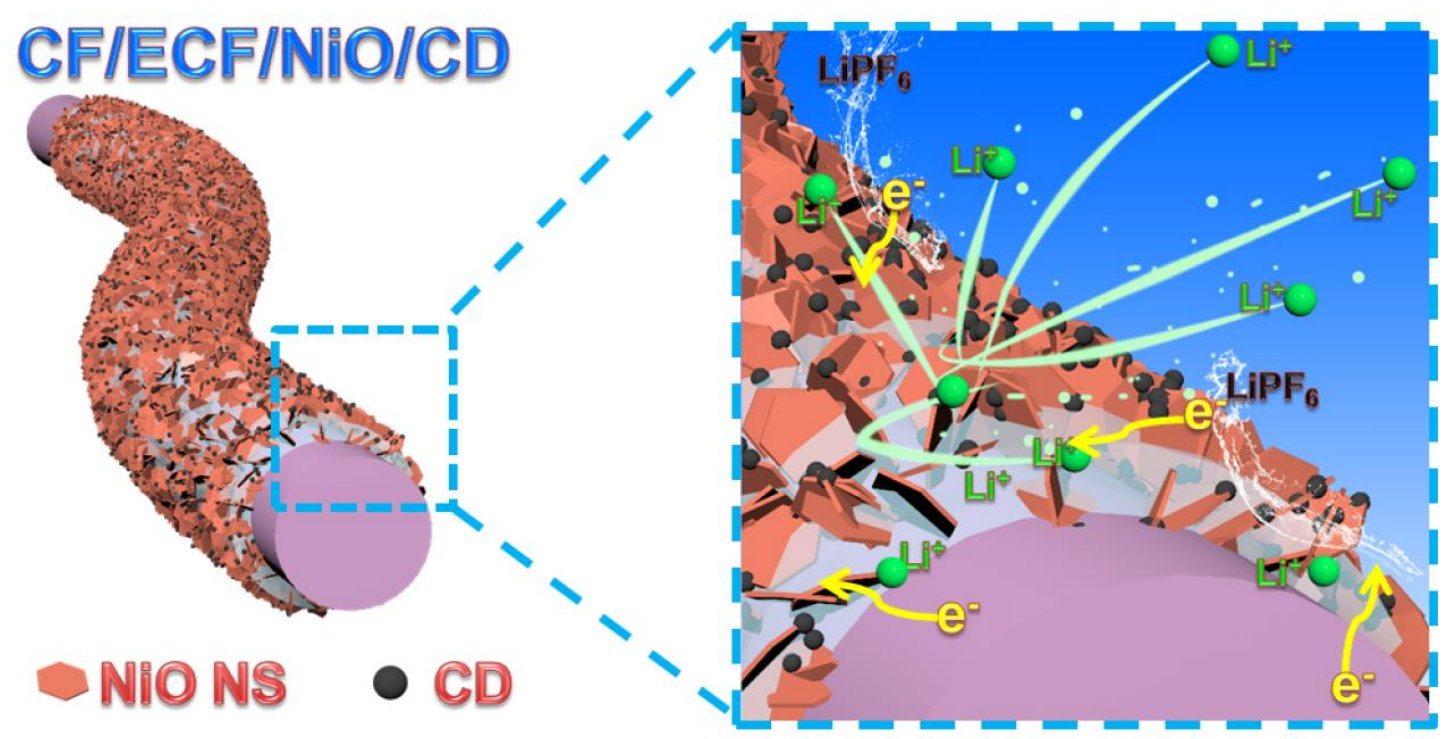

Scheme 1. Simplified interpretation of $\mathrm{CF} / \mathrm{ECF} / \mathrm{NiO} / \mathrm{CD}$ anode with bicontinuous $\mathrm{Li}$ ion and electron transfer routes.

The $\mathrm{CF} / \mathrm{ECF} / \mathrm{NiO} / \mathrm{CD}$ core-multishell battery electrode is designed to allow continuous transfer of electron through $\mathrm{CF} / \mathrm{ECF}, \mathrm{NiO}$ and $\mathrm{CD}$. (a) The porosity of the 
3D $\mathrm{CF} / \mathrm{ECF}$ attracts higher surface area which is beneficial for the introduction of more active sites as well as the interface of electrode/electrolyte towards easy and rapid absorption of Li-ion and electron transfer. The $\mathrm{CF} / \mathrm{ECF}$ plays the role of current collector/substrate, capacity contributor and excellent lighter free-standing and flexible scaffold. (b) The good adhesion of the porous $\mathrm{NiO}$ nanosheets to the porous exfoliated surface of $\mathrm{CF} / \mathrm{ECF}$ allows strong electronic interaction between the $\mathrm{CF} / \mathrm{ECF}$ and $\mathrm{NiO}$ nanosheets, which could enhances the diffusion of ion and kinetics of charge transportation towards high-rate performance and applications. (c) The coating of CDs that serves the following functions; (i) Because most TMOs are well known to exhibits poor conductivity and stability [6, 41], CDs enhances the conductivity of $\mathrm{NiO}$ nanosheets, which is very essential for further improving the kinetics of the entire electrode architecture leading to excellent cyclic and rate capability. (ii) as a protector for both the $\mathrm{NiO}$ nanosheets and entire multihybrid system i.e. protecting the $\mathrm{NiO}$ nanosheets from easy agglomeration leading to the minimization of active materials dissolution during cyclic stability performance and (iii) improves the coulombic efficiency $(\mathrm{CE})$ and capacity of $\mathrm{CF} / \mathrm{ECF} / \mathrm{NiO} / \mathrm{CD}$. Hence, such architecture is monolithic in nature allowing easy entrance of electrolyte to both sides of the nanosheets during Li-ion intercalation process, which create more opportunity for $\mathrm{Li}$-ion and electrons to directly react with $\mathrm{NiO}$.

\section{Full-cell Lithium Ion Batteries}

Based on the fact that $\mathrm{CF} / \mathrm{ECF} / \mathrm{NiO} / \mathrm{CD}$ exhibits the excellent areal capacity as anode material for LIBs, we utilized $\mathrm{CF} / \mathrm{ECF} / \mathrm{NiO} / \mathrm{CD}$ anode in the fabrication of full coin-cell LIBs and compare their performance with that of $\mathrm{CF} / \mathrm{NiO}$ anode. Commercial LNCMO casted on CF/ECF (denoted CF/ECF/LNCMO) was employed as cathode for reasonable comparison. Our previous work has 
shown that LNCMO casted on $\mathrm{CF} / \mathrm{ECF}$ displayed better Li-storage performance than that casted on $\mathrm{CF}$ as cathode material for LIBs [22]. $\mathrm{CF} / \mathrm{ECF} / \mathrm{NiO} / \mathrm{CD} / / \mathrm{CF} / \mathrm{ECF} / \mathrm{LNCMO}$ battery was then scaled-up to $45.0 \mathrm{~cm}^{2}$ soft-pack flexible battery design. The electrolyte/electrode ratio is $2.3 \mathrm{~g} \mathrm{Ah}^{-1}$ indicating that $2.3 \mathrm{~g}$ of $1 \mathrm{M} \mathrm{LiPF}_{6}$ (containing 1:1 by volume of EC/DMC) is required to achieve 1 Ah specific capacity. The digital image of the scale-up soft-pack flexible battery shows that the thickness of the battery is $0.10 \mathrm{~cm}$ as shown in Figure S22. According to the charge-discharge curves (Figure 7a) and $\mathrm{CV}$ curves (Figure S23) of devices, the working voltages of both $\mathrm{CF} / \mathrm{NiO}$-based and $\mathrm{CF} / \mathrm{ECF} / \mathrm{NiO} / \mathrm{CD}$-based batteries are $3.50 \mathrm{~V}$. The $\mathrm{CF} / \mathrm{ECF} / \mathrm{NiO} / \mathrm{CD} / / \mathrm{CF} / \mathrm{ECF} / \mathrm{LNCMO} \mathrm{LIB}$ could achieve an areal capacity of $41.33 \mathrm{mAh} \mathrm{cm}^{-2}$ at current density of $5 \mathrm{~mA}$, which is significantly higher than

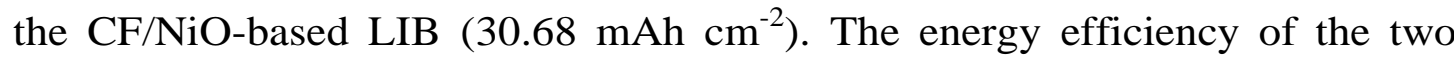
batteries, which depends on the overpotentials of galvanostatic curves in Figure 7a (i.e. the area beneath the galvanostatic curves) and were calculated based on the formula below[50-52];

Energy efficiency $=\frac{\text { Energy density }{ }_{(\text {discharge })}}{\text { Energy density }_{(\text {(charge })}} \times 100 \%$

Thus, the energy efficiency of the CF/ECF/NiO/CD-based LIB is $93 \%$, which is also higher than the $\mathrm{CF} / \mathrm{NiO}$-based LIB. At current value of $5 \mathrm{~mA}$, the $\mathrm{CF} / \mathrm{ECF} / \mathrm{NiO} / \mathrm{CD}$-based LIB exhibit excellent stability capacity of $40.89 \mathrm{mAh}$ $\mathrm{cm}^{-2}$ (i.e. retaining $98 \%$ of its initial capacity at $41.62 \mathrm{mAh} \mathrm{cm}^{-2}$ ) after 300 electrochemical cycles, unlike that of $\mathrm{CF} / \mathrm{NiO} / / \mathrm{CF} / \mathrm{ECF} / \mathrm{LNCMO}$, which could only deliver a capacity of $19.56 \mathrm{mAh} \mathrm{cm}^{-2}$ (i.e. $63 \%$ of its initial capacity at $30.68 \mathrm{mAh} \mathrm{cm}^{-2}$ (Figure 7b). Thus, the superior stability of $\mathrm{CF} / \mathrm{ECF} / \mathrm{NiO} / \mathrm{CD}$ over $\mathrm{CF} / \mathrm{NiO}$ can both be confirmed in the half and full cell LIBs. 


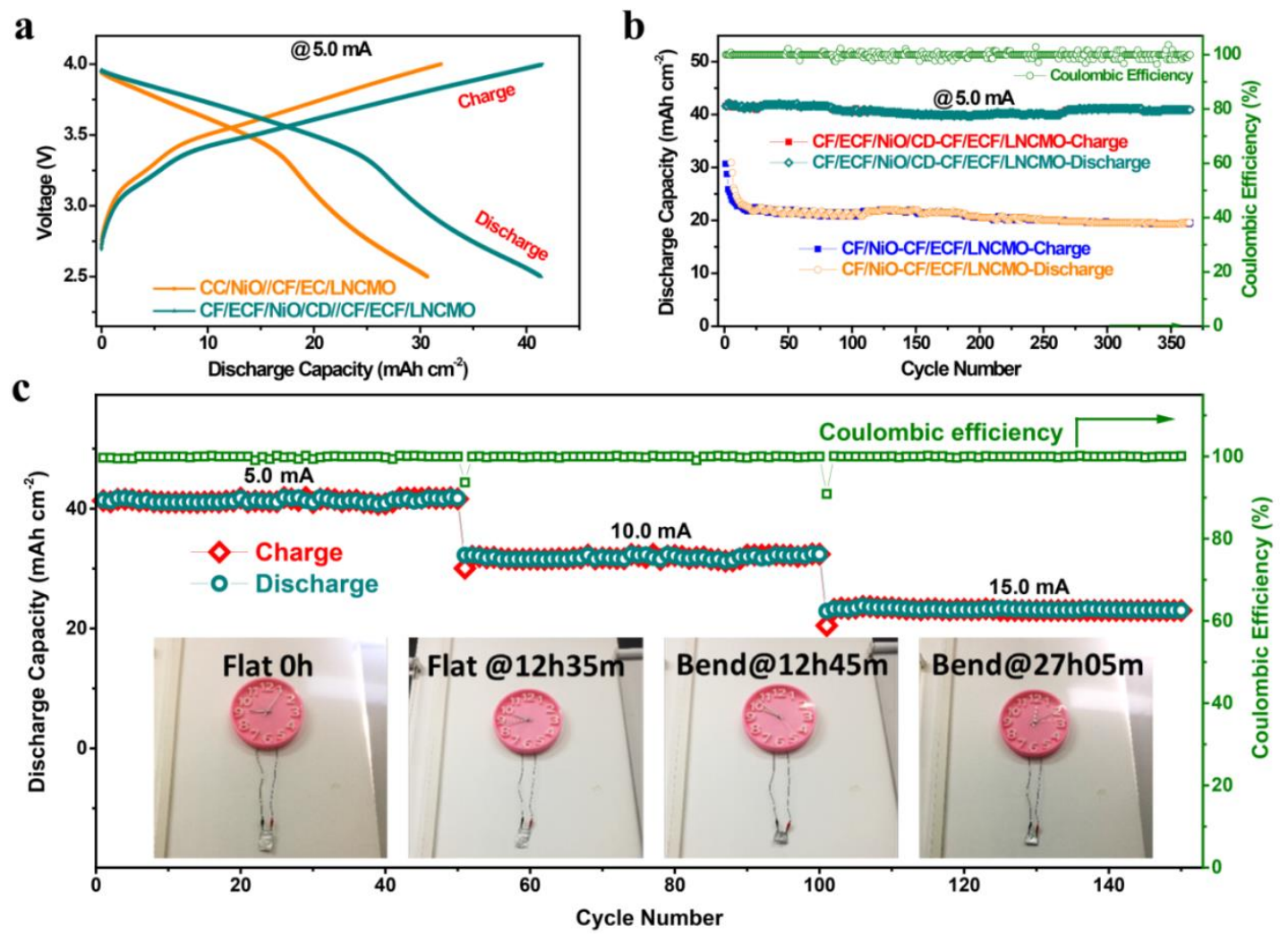

Fig. 7. Flexible full cell properties of the soft-pack flexible LIB soft-pack flexible LIB. a) Charge-discharge profiles and b) cyclic stability of $\mathrm{CF} / \mathrm{NiO} / / \mathrm{CF} / \mathrm{ECF} / \mathrm{LNCMO}$ and $\mathrm{CF} / \mathrm{ECF} / \mathrm{NiO} / \mathrm{CD} / / \mathrm{CF} / \mathrm{ECF} / \mathrm{LNCMO}$ full coin-cell batteries. c) Cycling rate capability of $\mathrm{CF} / \mathrm{ECF} / \mathrm{NiO} / \mathrm{CD} / / \mathrm{CF} / \mathrm{ECF} / \mathrm{LNCMO}$ soft-pack flexible LIB at the applied currents of 5.0, 10.0 and $15.0 \mathrm{~mA}$. Inset in "c" is the potential application of the soft-pack flexible LIB powering a wall-clock for $27 \mathrm{~h}$ at both flat and bending states.

Finally, the $\mathrm{CF} / \mathrm{ECF} / \mathrm{NiO} / \mathrm{CD} / / \mathrm{CF} / \mathrm{ECF} / \mathrm{LNCMO}$ FLIB was subjected to different current values of $5.0,10.0$ and $15.0 \mathrm{~mA}$ for 50 cycles each at after 50 folding and at $180^{\circ}$ bending angle. The flexible battery still retain its capacity delivering a high areal capacity of $41.33 \mathrm{mAh} \mathrm{cm}^{-2}$ when current of $5.0 \mathrm{~mA}$ was applied, which are equivalent to $413.3 \mathrm{mAh} \mathrm{cm}^{-3}$ (based on the thickness of the soft-pack battery, $0.1 \mathrm{~cm}$ ) and $134.5 \mathrm{mAh} \mathrm{g}^{-1}$ (based on the entire weight of the battery, $308 \mathrm{mg}$ ) Figure S24, S25 and Table S1]. The battery could also operate successfully at increasing current value up to $15 \mathrm{~mA}$ retaining an areal capacity of $12.59 \mathrm{mAh} \mathrm{cm}^{-2}\left(125.9 \mathrm{mAh} \mathrm{cm}^{-3}\right.$ and $\left.115.8 \mathrm{mAh} \mathrm{g}^{-1}\right)$. The flexible battery 
also maintained outstanding flexible stability up to 150 cycle (Figure 7c) and could also achieve a $201.7 \mathrm{Wh} \mathrm{kg}^{-1}\left(619.9 \mathrm{Wh} \mathrm{L}^{-1}\right)$ based on the entire weight of the battery. The $\mathrm{CF} / \mathrm{ECF} / \mathrm{NiO} / \mathrm{CD} / / \mathrm{CF} / \mathrm{ECF} / \mathrm{LNCMO} \mathrm{LIB}$ could power a wall-clock at the flat and bending states for more than $27 \mathrm{~h}$ after stability test owing to the flexibility of both the anode and cathode materials (Figure 7c inset). This suggests great potential application for flexible energy storage devices. Video demonstration of the device driving a wall clock at the flat and bending conditions before and after $27 \mathrm{~h}$ can be found in Figure SV1 and Figure SV2, respectively.

\section{Conclusions}

In conclusion, we have successfully established that constructing 3D selfstanding and monolithic electrode could enhance the areal capacity of LIB not only due to the capacity contribution from the surface functionalized flexible carbon fiber but also by tailoring the p-orbital center. The $3 \mathrm{D}$ monolithic flexible anode that consists of carbon fiber coated with $\mathrm{N}$-doped porous exfoliated carbon fiber, $\mathrm{NiO}$ and $\mathrm{CDs}$ (denoted $\mathrm{CF} / \mathrm{ECF} / \mathrm{NiO} / \mathrm{CD}$ ) exhibits a high reversible areal capacity of $3.97 \mathrm{mAh} \mathrm{cm}^{-2}$ at $0.25 \mathrm{~mA} \mathrm{~cm}^{-2}$, excellent rate performance capacity of $2.61 \mathrm{mAh} \mathrm{cm}^{-2}$ at $6.0 \mathrm{~mA} \mathrm{~cm}^{-2}$ and impressive stability

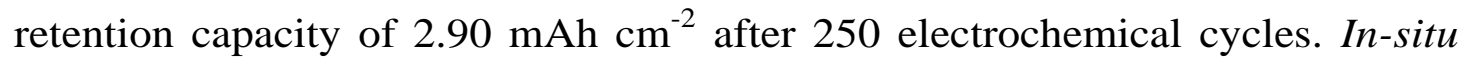
Raman, XPS and DFT studies persistently confirm that the improved Li-storage performance can be related to the capacity contribution from the flexible carbon-based current collector, coating of the CDs and shift in the p-orbital leading to strong electronic interaction within the $\mathrm{CF} / \mathrm{ECF} / \mathrm{NiO} / \mathrm{CD}$ systems. Moreover, $\mathrm{CF} / \mathrm{ECF} / \mathrm{NiO} / \mathrm{CD}$ was easily scaled-up as anode material to design a 
$45.0 \mathrm{~cm}^{2}$ soft-pack full LIB battery using commercial LNCMO as cathode. The soft-pack CF/ECF/NiO/CD-based LIBs delivers a high areal capacity, volumetric capacity and mass capacity of $41.33 \mathrm{mAh} \mathrm{cm}^{-2}, 413.3 \mathrm{mAh} \mathrm{cm}^{-3}$ and 134.5 $\mathrm{mAh} \mathrm{g}^{-1}$, respectively (equivalent to high energy density at $619.9 \mathrm{Wh} \mathrm{L}^{-1}$ or $201.7 \mathrm{Wh} \mathrm{kg}^{-1}$ ) at high current density of $5 \mathrm{~mA}$, showing a great potential application in developing high areal capacity flexible energy storage devices.

\section{Acknowledgements}

This work was supported by the Natural Science Foundation of China (21875292 and 21773315), Science Starting Foundation of Hunan University (531118010182) and China Postdoctoral Science Foundation (2018M640847 and 2019T120764).

\section{Conflict of interest}

The authors declare no competing financial interest.

\section{References}

[1] J. Ma, J. Sung, J. Hong, S. Chae, N. Kim, S.-H. Choi, G. Nam, Y. Son, S.Y. Kim, M. Ko, J. Cho, Towards maximized volumetric capacity via pore-coordinated design for large-volume-change lithium-ion battery anodes, Nat. Commun. 10 (2019) 475.

[2] J. Zheng, Q. Zhao, X. Liu, T. Tang, D.C. Bock, A.M. Bruck, K.R. Tallman, L.M. Housel, A.M. Kiss, A.C. Marschilok, E.S. Takeuchi, K.J. Takeuchi, L.A. Archer, Nonplanar Electrode Architectures for Ultrahigh Areal Capacity Batteries, ACS Energy Lett. 4 (2019) 271-275.

[3] L. Sheng, S. Liang, T. Wei, J. Chang, Z. Jiang, L. Zhang, Q. Zhou, J. Zhou, L. Jiang, Z. Fan, Space-confinement of $\mathrm{MnO}$ nanosheets in densely stacked graphene: 
Ultra-high volumetric capacity and rate performance for lithium-ion batteries, Energy Stor. Mater. 12 (2018) 94-102.

[4] B. Wang, J. Ryu, S. Choi, G. Song, D. Hong, C. Hwang, X. Chen, B. Wang, W. Li, H.-K. Song, S. Park, R.S. Ruoff, Folding Graphene Film Yields High Areal Energy Storage in Lithium-Ion Batteries, ACS Nano 12 (2018) 1739-1746.

[5] Y. Lu, L. Yu, X.W. Lou, Nanostructured Conversion-type Anode Materials for Advanced Lithium-Ion Batteries, Chem 4 (2018) 972-996.

[6] M. Zheng, H. Tang, L. Li, Q. Hu, L. Zhang, H. Xue, H. Pang, Hierarchically Nanostructured Transition Metal Oxides for Lithium-Ion Batteries, Adv. Sci. 5 (2018) 1700592.

[7] X. Tang, G. Chen, Z. Mo, D. Ma, S. Wang, J. Wen, L. Gong, L. Zhao, J. Huang, T. Huang, J. Luo, Controllable two-dimensional movement and redistribution of lithium ions in metal oxides, Nat. Commun. 10 (2019) 2888.

[8] N. Nitta, F. Wu, J.T. Lee, G. Yushin, Li-ion battery materials: present and future, Materials Today 18 (2015) 252-264.

[9] M. Li, J. Lu, Z. Chen, K. Amine, 30 Years of Lithium-Ion Batteries, Adv. Mater. $30(2018) 1800561$.

[10] M.-S. Balogun, W. Qiu, Y. Luo, H. Meng, W. Mai, A. Onasanya, T.K. Olaniyi, Y. Tong, A review of the development of full cell lithium-ion batteries: The impact of nanostructured anode materials, Nano Res. 9 (2016) 2823-2851.

[11] Y.-F. Li, Y.-H. Shi, S.-G. Wang, J.-H. Liu, J. Lin, Y. Xia, X.-L. Wu, C.-Y. Fan, J.-P. Zhang, H.-M. Xie, H.-Z. Sun, Z.-M. Su, Carbon/Binder-Free NiO@NiO/NF with In Situ Formed Interlayer for High-Areal-Capacity Lithium Storage, Adv. Energy Mater. 9 (2019) 1803690. 
[12] F. Zhang, C. Yang, H. Guan, Y. Hu, C. Jin, H. Zhou, L. Qi, 3D Copper Foam@ $\mathrm{FeO}_{\mathrm{x}}$ Nanoarrays as a High Areal Capacity and Stable Electrode for LithiumIon Batteries, ACS Applied Energy Materials 1 (2018) 5417-5427.

[13] L. Li, H.B. Wu, L. Yu, S. Madhavi, X.W. Lou, A General Method to Grow Porous $\alpha-\mathrm{Fe}_{2} \mathrm{O}_{3}$ Nanosheets on Substrates as Integrated Electrodes for Lithium-Ion Batteries, Adv. Mater. Interfaces 1 (2014) 1400050.

[14] R. Elango, A. Demortière, V. De Andrade, M. Morcrette, V. Seznec, Thick Binder-Free Electrodes for Li-Ion Battery Fabricated Using Templating Approach and Spark Plasma Sintering Reveals High Areal Capacity, Adv. Energy Mater. 8 (2018) 1703031.

[15] X. Han, Z. Zhang, G. Zheng, R. You, J. Wang, C. Li, S. Chen, Y. Yang, Scalable Engineering of Bulk Porous Si Anodes for High Initial Efficiency and High-ArealCapacity Lithium-Ion Batteries, ACS Appl. Mater. Interfaces 11 (2019) 714-721.

[16] Y. Yue, H. Liang, 3D Current Collectors for Lithium-Ion Batteries: A Topical Review, Small Methods 2 (2018) 1800056.

[17] M.-S. Balogun, W. Qiu, Y. Luo, Y. Huang, H. Yang, M. Li, M. Yu, C. Liang, P. Fang, P. Liu, Y. Tong, Improving the Lithium-Storage Properties of Self-Grown Nickel Oxide: A Back-Up from $\mathrm{TiO}_{2}$ Nanoparticles, ChemElectroChem 2 (2015) $1243-1248$.

[18] J. Zhu, Q. Wu, J. Key, M. Wu, P.K. Shen, Self-assembled superstructure of carbon-wrapped, single-crystalline $\mathrm{Cu}_{3} \mathrm{P}$ porous nanosheets: One-step synthesis and enhanced Li-ion battery anode performance, Energy Stor. Mater. 15 (2018) 75-81.

[19] J. Zhan, S. Deng, Y. Zhong, Y. Wang, X. Wang, Y. Yu, X. Xia, J. Tu, Exploring hydrogen molybdenum bronze for sodium ion storage: Performance enhancement by vertical graphene core and conductive polymer shell, Nano Energy 44 (2018) 265-271. 
[20] Z. Deng, H. Jiang, Y. Hu, Y. Liu, L. Zhang, H. Liu, C. Li, 3D Ordered Macroporous $\mathrm{MoS}_{2} @ \mathrm{C}$ Nanostructure for Flexible Li-Ion Batteries, Adv. Mater. 29 (2017) 1603020-1603026.

[21] X. Min, B. Sun, S. Chen, M. Fang, X. Wu, Y.g. Liu, A. Abdelkader, Z. Huang, T. Liu, K. Xi, R. Vasant Kumar, A textile-based $\mathrm{SnO}_{2}$ ultra-flexible electrode for lithium-ion batteries, Energy Stor. Mater. 16 (2019) 597-606.

[22] M.-S. Balogun, H. Yang, Y. Luo, W. Qiu, Y. Huang, Z.-Q. Liu, Y. Tong, Achieving high gravimetric energy density for flexible lithium-ion batteries facilitated by core-double-shell electrodes, Energy Environ. Sci. 11 (2018) 1859-1869.

[23] M.-S. Balogun, Y. Luo, F. Lyu, F. Wang, H. Yang, H. Li, C. Liang, M. Huang, Y. Huang, Y. Tong, Carbon Quantum Dot Surface-Engineered $\mathrm{VO}_{2}$ Interwoven Nanowires: A Flexible Cathode Material for Lithium and Sodium Ion Batteries, ACS Appl. Mater. Interfaces 8 (2016) 9733-9744.

[24] G. Kresse, J. Furthmüller, Efficient iterative schemes for ab initio total-energy calculations using a plane-wave basis set, Phys. Rev. B 54 (1996) 11169-11186.

[25] J.P. Perdew, K. Burke, M. Ernzerhof, Generalized Gradient Approximation Made Simple, Phys. Rev. Lett. 77 (1996) 3865-3868.

[26] S. Grimme, Semiempirical GGA-type density functional constructed with a longrange dispersion correction, J. Comput. Chem. 27 (2006) 1787-1799.

[27] E. Sanville, S.D. Kenny, R. Smith, G. Henkelman, Improved grid-based algorithm for Bader charge allocation, J. Comput. Chem. 28 (2007) 899-908.

[28] M.-S. Balogun, W. Qiu, F. Lyu, Y. Luo, H. Meng, J. Li, W. Mai, L. Mai, Y. Tong, All-flexible lithium ion battery based on thermally-etched porous carbon cloth anode and cathode, Nano Energy 26 (2016) 446-455. 
[29] S. Xie, H. Su, W. Wei, M. Li, Y. Tong, Z. Mao, Remarkable photoelectrochemical performance of carbon dots sensitized $\mathrm{TiO}_{2}$ under visible light irradiation, J. Mater. Chem. A 2 (2014) 16365-16368.

[30] W. Li, Y. Liu, M. Wu, X. Feng, S.A.T. Redfern, Y. Shang, X. Yong, T. Feng, K. Wu, Z. Liu, B. Li, Z. Chen, J.S. Tse, S. Lu, B. Yang, Carbon-Quantum-Dots-Loaded Ruthenium Nanoparticles as an Efficient Electrocatalyst for Hydrogen Production in Alkaline Media, Adv. Mater. 30 (2018) 1800676.

[31] J. Briscoe, A. Marinovic, M. Sevilla, S. Dunn, M. Titirici, Biomass-Derived Carbon Quantum Dot Sensitizers for Solid-State Nanostructured Solar Cells, Angew. Chem. Int. Ed. 54 (2015) 4463-4468.

[32] D. Su, H.-S. Kim, W.-S. Kim, G. Wang, Mesoporous Nickel Oxide Nanowires: Hydrothermal Synthesis, Characterisation and Applications for Lithium-Ion Batteries and Supercapacitors with Superior Performance, Chem. Eur. J. 18 (2012) 8224-8229. [33] H. Song, J. Su, C. Wang, In Situ Subangstrom-Thick Organic Engineering Enables Mono-scale, Ultrasmall ZnO Nanocrystals for a High Initial Coulombic Efficiency, Fully Reversible Conversion, and Cycle-Stable Li-Ion Storage, Adv. Energy Mater. 01900426.

[34] R. Hu, Y. Ouyang, T. Liang, X. Tang, B. Yuan, J. Liu, L. Zhang, L. Yang, M. Zhu, Inhibiting grain coarsening and inducing oxygen vacancies: the roles of $\mathrm{Mn}$ in achieving a highly reversible conversion reaction and a long life $\mathrm{SnO}_{2}-\mathrm{Mn}-$ graphite ternary anode, Energy Environ. Sci. 10 (2017) 2017-2029.

[35] J. Li, S. Hwang, F. Guo, S. Li, Z. Chen, R. Kou, K. Sun, C.-J. Sun, H. Gan, A. Yu, E.A. Stach, H. Zhou, D. Su, Phase evolution of conversion-type electrode for lithium ion batteries, Nat. Commun. 10 (2019) 2224. 
[36] C. Guan, X. Wang, Q. Zhang, Z. Fan, H. Zhang, H.J. Fan, Highly stable and reversible lithium storage in $\mathrm{SnO}_{2}$ nanowires surface coated with a uniform hollow shell by atomic layer deposition, Nano Lett. 14 (2014) 4852-4858.

[37] Y. Luo, M.-S. Balogun, W. Qiu, R. Zhao, P. Liu, Y. Tong, Sulfurization of $\mathrm{FeOOH}$ nanorods on a carbon cloth and their conversion into $\mathrm{Fe}_{2} \mathrm{O}_{3} / \mathrm{Fe}_{3} \mathrm{O}_{4}$-S coreshell nanorods for lithium storage, Chem. Commun. 51 (2015) 13016-13019.

[38] M.-S. Balogun, W. Qiu, J. Jian, Y. Huang, Y. Luo, H. Yang, C. Liang, X. Lu, Y. Tong, Vanadium Nitride Nanowire Supported $\mathrm{SnS}_{2}$ Nanosheets with High Reversible Capacity as Anode Material for Lithium Ion Batteries, ACS Appl. Mater. Interfaces 7 (2015) 23205-23215.

[39] W. Qiu, M.-S. Balogun, Y. Luo, K. Chen, Y. Zhu, X. Xiao, X. Lu, P. Liu, Y. Tong, Three-dimensional $\mathrm{Fe}_{3} \mathrm{O}_{4}$ Nanotube Array on Carbon Cloth Prepared from A Facile Route for Lithium ion Batteries, Electrochim. Acta 193 (2016) 32-38.

[40] X. Huang, G. Diao, S. Li, M.-S. Balogun, N. Li, Y. Huang, Z.-Q. Liu, Y. Tong, Enhanced lithium storage performance of porous exfoliated carbon fibers via anchored nickel nanoparticles, RSC Adv. 8 (2018) 17056-17059.

[41] Y. Zhao, X. Li, B. Yan, D. Xiong, D. Li, S. Lawes, X. Sun, Recent Developments and Understanding of Novel Mixed Transition-Metal Oxides as Anodes in Lithium Ion Batteries, Adv. Energy Mater. 6 (2016) 1502175.

[42] D. Chao, C. Zhu, X. Xia, J. Liu, X. Zhang, J. Wang, P. Liang, J. Lin, H. Zhang, Z.X. Shen, Graphene Quantum Dots Coated $\mathrm{VO}_{2}$ Arrays for Highly Durable Electrodes for Li and Na Ion Batteries, Nano Lett. 15 (2014) 565-573.

[43] X. Wang, L. Lv, Z. Cheng, J. Gao, L. Dong, C. Hu, L. Qu, High-Density Monolith of N-Doped Holey Graphene for Ultrahigh Volumetric Capacity of Li-Ion Batteries, Adv. Energy Mater. 6 (2016) 1502100. 
[44] M. Jing, J. Wang, H. Hou, Y. Yang, Y. Zhang, C. Pan, J. Chen, Y. Zhu, X. Ji, Carbon quantum dot coated $\mathrm{Mn}_{3} \mathrm{O}_{4}$ with enhanced performances for lithium-ion batteries, J. Mater. Chem. A 3 (2015) 16824-16830.

[45] J.-X. Feng, J.-Q. Wu, Y.-X. Tong, G.-R. Li, Efficient Hydrogen Evolution on Cu Nanodots-Decorated $\mathrm{Ni}_{3} \mathrm{~S}_{2}$ Nanotubes by Optimizing Atomic Hydrogen Adsorption and Desorption, J. Am. Chem. Soc. 140 (2018) 610-617.

[46] C. Chen, X. Xie, B. Anasori, A. Sarycheva, T. Makaryan, M. Zhao, P. Urbankowski, L. Miao, J. Jiang, Y. Gogotsi, $\mathrm{MoS}_{2}$-on-MXene Heterostructures as Highly Reversible Anode Materials for Lithium-Ion Batteries, Angew. Chem. Int. Ed. 57 (2018) 1846-1850.

[47] Y. Chu, L. Guo, B. Xi, Z. Feng, F. Wu, Y. Lin, J. Liu, D. Sun, J. Feng, Y. Qian, S. Xiong, Embedding $\mathrm{MnO} @ \mathrm{Mn}_{3} \mathrm{O}_{4}$ Nanoparticles in an N-Doped-Carbon Framework Derived from Mn-Organic Clusters for Efficient Lithium Storage, Adv. Mater. 30 (2018) 1704244.

[48] K. Xu, X. Liu, J. Liang, J. Cai, K. Zhang, Y. Lu, X. Wu, M. Zhu, Y. Liu, Y. Zhu, G. Wang, Y. Qian, Manipulating the Redox Kinetics of Li-S Chemistry by Tellurium Doping for Improved Li-S Batteries, ACS Energy Lett. 3 (2018) 420-427.

[49] J. Zhou, X. Liu, L. Zhu, J. Zhou, Y. Guan, L. Chen, S. Niu, J. Cai, D. Sun, Y. Zhu, J. Du, G. Wang, Y. Qian, Deciphering the Modulation Essence of p Bands in Co-Based Compounds on Li-S Chemistry, Joule 2 (2018) 2681-2693.

[50] Y. Cao, M. Li, J. Lu, J. Liu, K. Amine, Bridging the academic and industrial metrics for next-generation practical batteries, Nat. Nanotechnol. 14 (2019) 200-207. [51] A. Eftekhari, Energy efficiency: a critically important but neglected factor in battery research, Sustainable Energy \& Fuels 1 (2017) 2053-2060. 
[52] L. Hu, Y. Gao, T. Xiong, D. Adekoya, W. Qiu, H. Yang, M.S. Balogun, S. Zhang, A. Pan, Y. Li, Y. Tong, Surface functionalized 3D carbon fibers boosts the lithium storage behaviour of transition metal oxide nanowires via strong electronic interaction and tunable adsorption energy, Nanoscale Horiz. 4 (2019) 1402-1410. 